\title{
A 5,000-Year Fire History in the Strait of Georgia Lowlands, British Columbia, Canada
}

\author{
Sinead F. Murphy ${ }^{1}$, Marlow G. Pellatt ${ }^{1,2 *}$ and Karen E. Kohfeld ${ }^{1}$ \\ ${ }^{1}$ School of Resource and Environmental Management, Simon Fraser University, Burnaby, BC, Canada, ${ }^{2}$ Parks Canada, \\ Natural Resource Conservation, Protected Areas Establishment and Conservation Directorate, Vancouver, BC, Canada
}

Improved knowledge of long-term fire regimes and climate-fire-human relationships are important for effective management of forested ecosystems. In this study, we use two, high-resolution sedimentary-charcoal records to provide new, mid to late Holocene fire histories for the driest forests in south coastal British Columbia, Canada: Somenos Lake in the Moist Maritime Coastal Douglas Fir (CDFmm) forests on southeastern Vancouver Island and Chadsey Lake in the Dry Maritime Coastal Western Hemlock (CWHdm) forests in the central Fraser Valley. Peak fire frequency at Somenos Lake in southeast Vancouver Island was highest prior to 3,500 cal yr BP at 9.5 fires per 1,000 years (at $\sim 4,500$ cal yr BP), with a mean fire return interval of 188 years (122-259) and 24 fire peaks for the 4,855 year record. Peak fire frequency at Chadsey Lake in the Fraser Valley of the Lower Mainland of BC was highest (5.9) at 2,736 cal yr BP but fairly uniform from $\sim 4,300$ to $2,500 \mathrm{cal}$ yr BP. The mean fire return interval at Chadsey Lake was 214 years (150-285) with 15 fire peaks for the $\sim 4,258$ year record. The fire history for Chadsey Lake appears to be strongly tied to broad regional climate patterns for the region whereas the variability in the Somenos Lake fire record displays a more complex pattern likely the result of the interplay between climatic and anthropogenic factors. Our results show how different age models using long- vs. short-term temporal scales of analysis can affect fire history interpretation and highlight the importance of considering spatial variability when interpreting mechanisms driving fire activity in this region.

${ }^{*}$ Correspondence:

Marlow G. Pellat

marlow.pellatt@canada.ca

Specialty section: This article was submitted to Paleoecology,

a section of the journal

Frontiers in Ecology and Evolution

Received: 02 October 2018

Accepted: 08 March 2019

Published: 10 April 2019

Citation:

Murphy SF, Pellatt MG and Kohfeld KE (2019) A 5,000-Year Fire

History in the Strait of Georgia Lowlands, British Columbia, Canada.

Front. Ecol. Evol. 7:90.

Keywords: charcoal analysis, paleoecology, fire history, ecological restoration, British Columbia, Canada, climate change, Pacific Northwest

\section{INTRODUCTION}

Knowledge of long-term fire regimes and climate-fire-human relationships has the potential to inform effective fire management plans for forested ecosystems, particularly in the drier forest regions of southwest British Columbia (BC), Canada such as the endangered Garry oak (Quercus garryana) ecosystems (GOEs), ranging from south coastal $\mathrm{BC}$ to south-central California. These ecosystems are threatened by stressors including fragmentation, invasive species, and habitat loss (Fuchs, 2001), but the overarching change in ecosystem function is likely the result of post-settlement fire suppression and the subsequent encroachment by conifers and other species (MacDougall et al., 2004).

While long-term fire histories could potentially help to inform fire management strategies incorporated into GOE restoration plans, existing long-term records are limited by several factors. Charcoal reconstructions for south coastal forests of British Columbia and the Pacific Northwest 
are based solely on short time periods $(<1,800$ years $)$ (Gavin et al., 2003; Lucas and Lacourse, 2013; Pellatt et al., 2015), have coarse resolution (>100 $\mathrm{yr} / \mathrm{cm})$, and/or use insufficient chronological control (i.e., no ${ }^{210} \mathrm{~Pb}$ and few ${ }^{14} \mathrm{C}$ age constraints) (Wainman and Mathewes, 1987; Gavin et al., 2001, 2013; Brown and Hebda, 2002a,b; Brown and Hebda, 2003; Hallett et al., 2003; Prichard et al., 2009; Walsh et al., 2015) (S1 Supporting Information for Regional Study Sites). Furthermore, existing tree ring records tend be of short time ranges of $<100$ years (Pellatt et al., 2007; Dunwiddie et al., 2011; Pellatt and Gedalof, 2014). Finally, no paleoecological study has assessed the variability of fire disturbances and assessed the influence of climate and human activity on fire occurrence in Dry Maritime Coastal Western Hemlock (CWHdm) forests in the central Fraser Valley.

Here we reconstruct long-term fire histories of two forest types from two lake sites in coastal BC's Strait of Georgia Lowlands (CDFmm and CWHdm) to understand the local fire history of the mid to late Holocene (ca. 5,000 cal yr BP to present). We place these fire histories within the context of previous studies of fire activity, climate, and human habitation over the last 5,000 years in the Pacific Northwest of North America (Figure 1; S1 Supporting Information for Regional Study Sites), to assess synchrony of fire occurrence and evaluate how variations in climate and anthropogenic land-use have influenced fire occurrence over time. Finally, we use high-resolution charcoal analysis with strong chronological control $\left({ }^{210} \mathrm{~Pb}\right.$ and AMS $\left.-{ }^{14} \mathrm{C}\right)$, and examine the impact of age control and the temporal scale of analysis on our interpretation of fire history characteristics.

\section{METHODS}

\section{Study Area: Strait of Georgia Lowlands, BC}

The Strait of Georgia Lowlands encompasses southeastern Vancouver Island, the Gulf Islands, and the Lower Mainland of BC. Its modern cool Mediterranean climate is dominated by the Aleutian Low pressure system in winter (a semi-permanent, subpolar area of low pressure located in the Gulf of Alaska), which delivers abundant precipitation to the coast (Walker and Pellatt, 2003). In spring and summer, the Pacific High pressure system brings dry air from the northwest that blocks westerly storms and produces warm dry conditions that increase the duration and severity of droughts and forest fires (Agee, 1993; Gedalof et al., 2005). The orographic effects of the Vancouver Island and Coast Mountain Ranges produce sharp, east-west precipitation gradients that result in strong local variation in the extent of summer drought and forest fires (Figure 1).

\section{Study Sites}

Sediment cores were retrieved from Somenos and Chadsey Lakes. We selected these sites based on their proximity to GOEs, CDFmm, and CWHdm forests, and because of their small catchment areas, which have previously been shown to provide better local fire history reconstructions (Whitlock and Millspaugh, 1996; Whitlock and Larson, 2001).

Somenos Lake is located on southeastern Vancouver Island $\left(48.48^{\circ} \mathrm{N}, 123.42^{\circ} \mathrm{W}\right.$; 16 masl) (Figure 1j) in the CDFmm biogeoclimatic zone. The lake has a 97 ha surface area with a maximum depth of $6.5 \mathrm{~m}$, three inflows (Richards, Bings Menzies, and Averill creeks), and one outflow (Somenos Creek). The 7,000 ha watershed is situated in the CDFmm biogeoclimatic zone in the rainshadow of the Insular Mountains and is characterized by warm, dry summers and wet, mild winters (Meidinger and Pojar, 1991). The mean annual precipitation is $\sim 1,500 \mathrm{~mm} / \mathrm{yr}$ (Environment Canada, 2015). The area surrounding the lake is relatively flat and consists of a range of wetland types and limited mature overstory canopy that includes Pacific willow (Salix lucida), Scouler's willow (Salix scouleriana), Garry oak (Quercus garryana), and Black cottonwood (Populus balsamifera trichocarpa) (Rasmussen, 2012). The Somenos Garry Oak Protected Area is located on the southeastern end of the lake.

Chadsey Lake is located on the north-facing side of Sumas Mountain in the central Fraser Valley $\left(49.07^{\circ} \mathrm{N}, 122.08^{\circ} \mathrm{W}\right.$; 620 masl) (Figure $\mathbf{l h}$ ) in the CWHmm biogeoclimatic zone. The lake has a 5.5 ha surface area with a maximum depth of $16 \mathrm{~m}$, one inflow (Chadsey Creek), and no known outflowing streams. The watershed is situated in the CWHdm biogeoclimatic zone and receives a mean annual precipitation of $\sim 1,540$ $\mathrm{mm} / \mathrm{yr}$ (Environment Canada, 2015). Western hemlock (Tsuga heterophylla), Western redcedar (Thuja plicata), and Douglas-fir (Pseudotsuga menziesii) dominate the open canopy (Meidinger and Pojar, 1991). A steep slope is located on the south side of the lake and a 20 ha stand of Garry oak is located on the lower, steep southeast-facing slope of the mountain.

\section{Fieldwork}

In 2013, a $4.94 \mathrm{~m}$ composite core (i.e., $0.54 \mathrm{~m}$ surface core and $4.4 \mathrm{~m}$ piston core) was retrieved from Somenos Lake using a $5 \mathrm{~cm}$ diameter modified Livingston piston corer (Wright et al., 1984) and a $5 \mathrm{~cm}$ diameter plexiglass tube connected to the Livingston. In 2014, a $5.08 \mathrm{~m}$ composite core (i.e., $0.42 \mathrm{~m}$ surface core and $4.66 \mathrm{~m}$ piston core) was collected from Chadsey Lake using a $7.6 \mathrm{~cm}$ diameter modified Glew gravity corer (Glew, 1988) and a $5 \mathrm{~cm}$ diameter modified Livingston piston corer (Wright et al., 1984). In both cases, the sediment-water interface was intact; however, the entire sedimentary sequence since the last deglaciation (ca. 13,700 cal yr BP (Pellatt et al., 2002) was only retrieved in the Somenos Lake core. The lithologic characteristics of the surface cores were documented in the field, and the surface cores were extruded on-site at $1 \mathrm{~cm}$ intervals using a closeinterval sectioning device (Glew, 1988). The lithology of each piston core was described after they were split longitudinally and photographed in the laboratory.

\section{Laboratory} Chronology

Sediment chronology and mass accumulation rates were estimated from ${ }^{210} \mathrm{~Pb}$ Constant Rate of Supply (CRS) models and Bayesian age-depth models (Blaauw and Christen, 2011; Bacon v $2.2^{1}$ based on ${ }^{210} \mathrm{~Pb}$ and AMS- ${ }^{14} \mathrm{C}$ age determinations and Mount Mazama tephra layers (S2 Table). ${ }^{210} \mathrm{~Pb}$ dating was performed by MyCore Scientific Inc. and

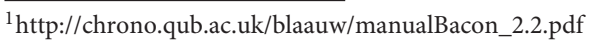




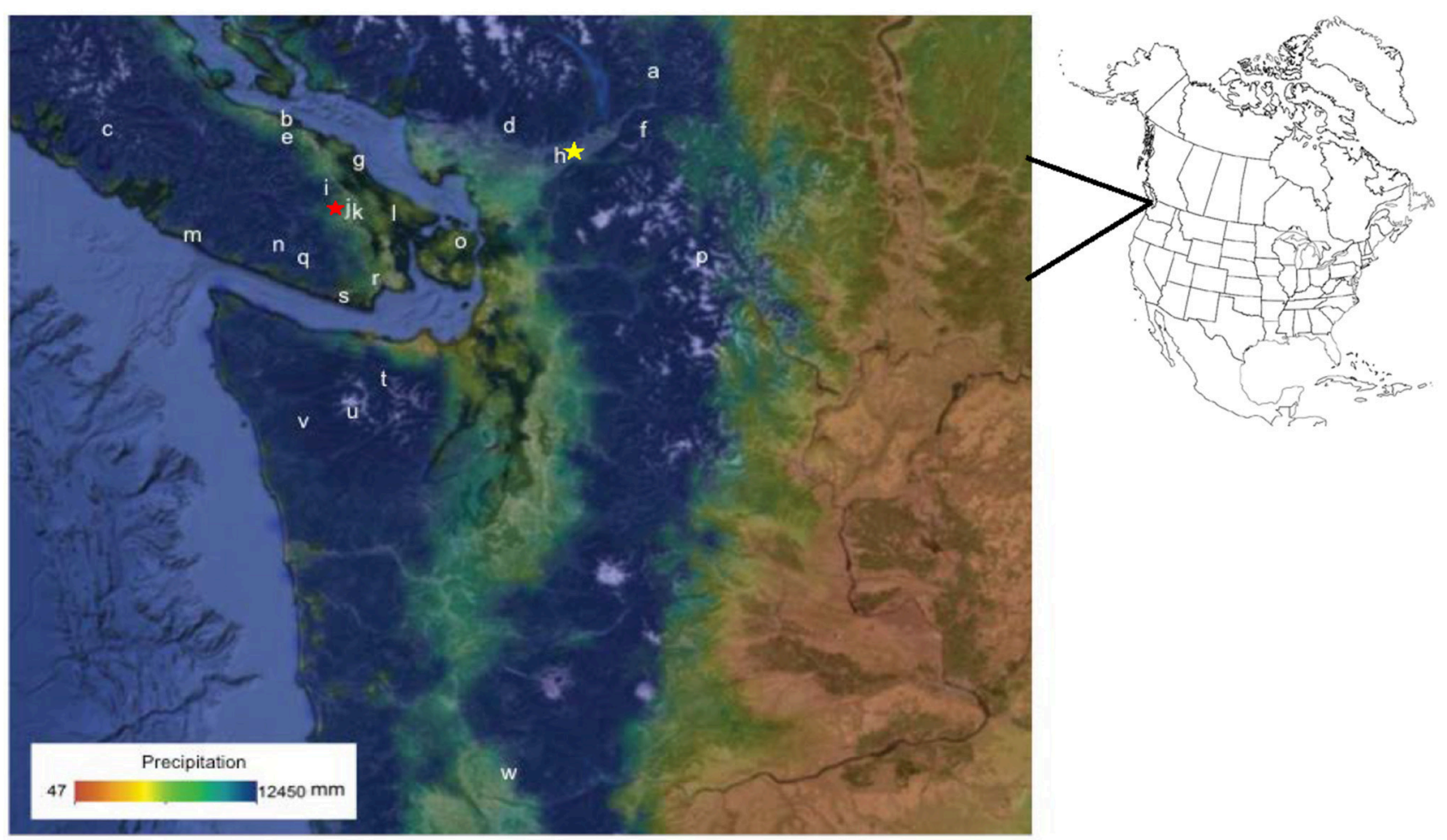

FIGURE 1 | Map of the Strait of Georgia Lowlands in western North America showing Somenos Lake ( $\mathrm{j}$ and red star) on Vancouver Island and Chadsey Lake (h and yellow star) in the Fraser Valley. Location of study area in relation to inset map of North America Study sites include: (a) Frozen Lake (Hallett et al., 2003); (b) Enos Lake (Brown and Hebda, 2002a); (c) Clayoquot Lake (Gavin et al., 2003); (d) Marion Lake (Wainman and Mathewes, 1987); (e) Boomerang Lake (Brown and Hebda, 2002a); (f) Mt. Barr Cirque Lake (Hallett et al., 2003); (g) Valdes Island On-site (i.e., Shingle Point) and Off-site Bogs; (Derr, 2014) (h) Chadsey Lake (this study); (i) Porphyry Lake (Brown and Hebda, 2003); (j) Somenos Lake (this study); (k) Quamichan Lake (Pellatt et al., 2015); (I) Roe Lake (Lucas and Lacourse, 2013; Pellatt et al., 2015); (m) Whyac Lake (Brown and Hebda, 2002b); (n) Pixie Lake (Brown and Hebda, 2002b); (o) Mount Constitution Small Hollow sites (Sugimura et al., 2008); (p) Panther Potholes (Prichard et al., 2009); (q) Walker Lake (Brown and Hebda, 2003); (r) Florence Lake (Pellatt et al., 2015); (s) East Sooke Fen (Brown and Hebda, 2002b); (t) Moose Lake (Gavin et al., 2001); (u) Martins Lake (Gavin et al., 2001); (v) Yahoo Lake (Gavin et al., 2013); and (w) Battle Ground Lake (Walsh et al., 2008). Base layer is from Climate WNA (Wang et al., 2012) using PRISM precipitation data (Daly et al., 2002). Site locations available in S1 Supporting Information for Regional Study Sites

AMS- ${ }^{14} \mathrm{C}$ dating of macrofossil, pollen, and bulk sediment samples was completed by the Center for Accelerator Mass Spectrometry (CAMS) at Lawrence Livermore National Laboratory. Macrofossil samples were washed with distilled water, and pollen samples were extracted using a procedure modified from Brown et al. (1989). AMS ${ }^{14} \mathrm{C}$ ages were converted to calendar years before present (cal yr BP) using CALIB 7.0.2 (Stuiver and Reimer, 1993) and the IntCal13.14c dataset (Reimer et al., 2013).

The Chadsey Lake composite core chronology was based on nine ${ }^{210} \mathrm{~Pb}$ age determinations and a constant rate of supply (CRS) model (Appleby and Oldfield, 1977) incorporated into a Bayesian age model that included four calibrated AMS- ${ }^{14} \mathrm{C}$ dates (Bacon v2.2), and the Mount Mazama Tephra [7590 (75147666)] (Figure 2A).

The chronology for the Somenos Lake composite core was based on $12{ }^{210} \mathrm{~Pb}$ age determinations and a CRS model incorporated into a Bayesian age model that included three calibrated AMS- ${ }^{14} \mathrm{C}$ dates, and the Mount Mazama Tephra [7590 (7514-7666)] (Figure 2B).

\section{Charcoal Analysis}

We conducted several tests with different charcoal extraction methods to establish which method provides the best representation of charcoal abundance, size, and shape found in the original sample (S3 Text). We then sampled $1 \mathrm{~cm}^{3}$ of sediment from contiguous, $1 \mathrm{~cm}$ intervals and soaked samples in a $5 \%\left(\mathrm{NaPO}_{3}\right)_{6}$ solution for $24 \mathrm{~h}$ and a $6 \% \mathrm{H}_{2} \mathrm{O}_{2}$ solution for $1 \mathrm{~h}$ to disaggregate sediment and remove non-charcoal, organic material. Samples were wet-sieved through a $125 \mu \mathrm{m}$ sieve and placed in a $30^{\circ} \mathrm{C}$ oven overnight. Samples were then placed on a transparent, $1 \mathrm{~cm}$ gridded counting coaster, and charcoal particles were identified under a Leica ${ }^{\circledR}$ M205C stereomicroscope based on brittleness, reflectance, and evidence of wood or plant cell structure (Clark and Royall, 1995).

The software package CharAnalysis (Higuera et al., 2009) (https://sites.google.com/site/charanalysis/) was used to calculate charcoal accumulation rate $\left(\mathrm{CHAR}\right.$, pieces $\left./ \mathrm{cm}^{2} / \mathrm{yr}\right)$, isolate charcoal peaks, and estimate mean fire return interval (mFRI), fire frequency, and fire-episode (peak) magnitude. The median temporal resolution of each core (Somenos, 10 years; Chadsey, 


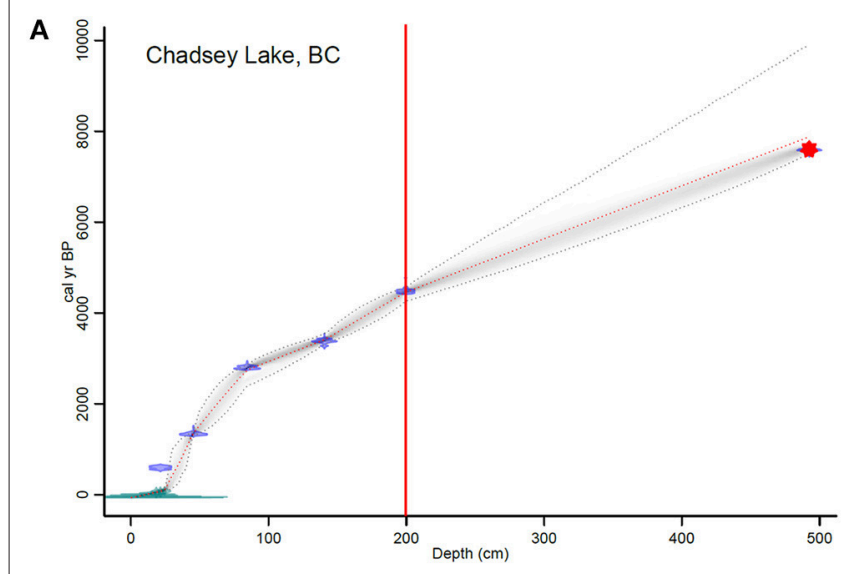

B

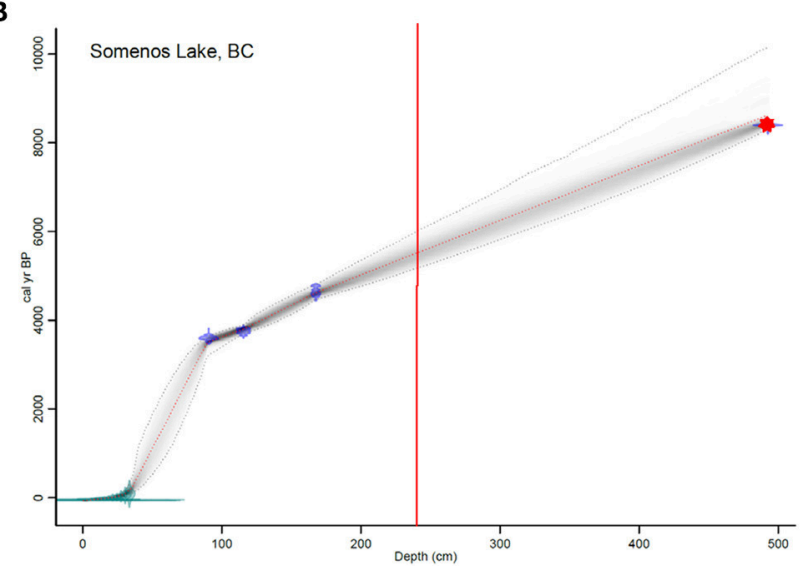

C

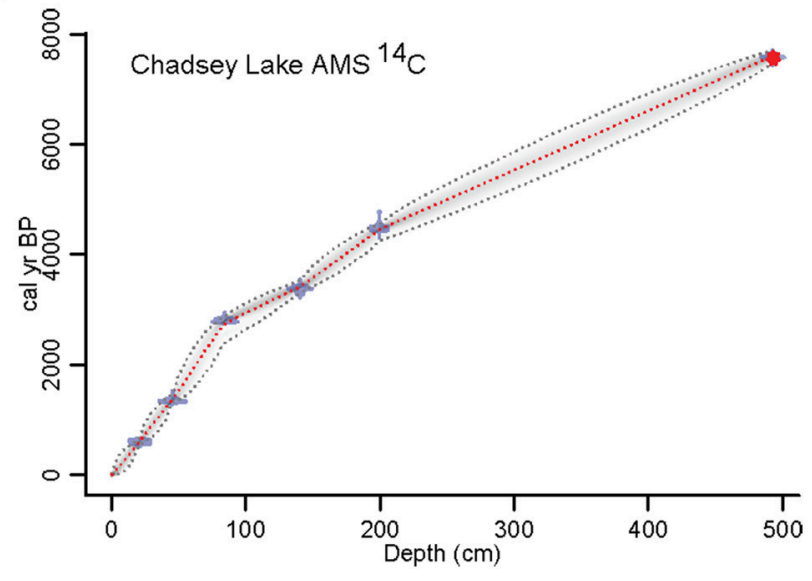

FIGURE 2 | Bayesian age-depth models for Somenos and Chadsey lakes composite cores. (A) Age-depth model (cm/yr) for Chadsey Lake using ${ }^{210} \mathrm{~Pb}$ ages based on Constant Rate of Supply Model (SRS), AMS ${ }^{14} \mathrm{C}$ dates and Mount Mazama tephra (7,590 cal yr BP) incorporated into a Bayesian age model (Bacon v2.2). (B) Age-depth model (cm/yr) for Somenos Lake using ${ }^{210} \mathrm{~Pb}$ ages based on Constant Rate of Supply Model (SRS), AMS ${ }^{14} \mathrm{C}$ dates and Mount Mazama tephra (7,590 cal yr BP) incorporated into a Bayesian age model. (C) Age-depth model (cm/yr) for Chadsey Lake using AMS ${ }^{14} \mathrm{C}$ dates and Mount Mazama tephra (7,590 cal yr BP) incorporated into a Bayesian age model. For (A,B) green represents ${ }^{210} \mathrm{~Pb}$ ages, blue represents $\mathrm{AMS}{ }^{14} \mathrm{C}$ ages, and the red star represents Mazama tephra. The red line indicates the lower limit of charcoal analyses. In (C) blue represents AMS ${ }^{14} \mathrm{C}$ ages and the red star represents Mazama tephra.
16 years) was used to interpolate charcoal concentrations $\left(\right.$ particles $/ \mathrm{cm}^{3}$ ) and sediment accumulation rates $(\mathrm{cm} / \mathrm{yr})$ to regularly spaced time intervals. CHAR was calculated by multiplying the interpolated charcoal concentrations by the interpolated sediment accumulation rates.

Charcoal peaks were isolated from CHAR by decomposing CHAR into a slowly varying background component and a more rapidly varying peaks component (Clark et al., 1996; Long et al., 1998). The background component indicates the long-term changes in fuel characteristics, secondary charcoal accumulation, and sediment mixing (Higuera et al., 2007). The peaks component represents individual "fire episodes" (i.e., one or more fire events occurring within the duration of a charcoal peak) and noise (Long et al., 1998). To calculate the background component, we used a Lowess smoother robust to outliers and selected 1,200- and 700-years window widths for the Somenos and Chadsey Lake CHARs, respectively, to maximize the signalto-noise ratios and goodness of fit measures for each record.

To isolate fire-related from non-fire-related peaks, we used a Gaussian mixture distribution to model noise within the peaks component of CHAR and selected a 99th percentile local threshold value for the mixture model. Fire related peaks were screened to eliminate statistically insignificant peaks (i.e., ones with greater than a $5 \%$ chance of coming from the same Poissondistributed population as the minimum charcoal count within the preceding 75 years) based on a non-parametric KolmogorovSmirnov goodness-of-fit test (Higuera et al., 2008).

To estimate mFRI and fire frequency (fires/1,000 yr), we selected a 1,000-years moving window to smooth the fire-related peaks component of CHAR. We calculated mFRI by averaging the time period between fire episodes for the entire composite record and for three temporal zones. Zones were based on documented shifts in climate and human habitation during the mid-to-late Holocene. Zone 1 (ca. 5,000-3,500 cal yr BP) marks the end of the Mesothermic period (Mathewes and Heusser, 1981; Pellatt and Mathewes, 1997; Walker and Pellatt, 2003); Zone 2 (3,500-2,000 cal yr BP) marks the onset of Neoglacial conditions ca. 3,500 cal yr BP (Walker and Pellatt, 2003); and Zone 3 (2,000 cal yr BP to present) is characterized by the development of complex Indigenous societies (Brown and Hebda, 2002a).

Fire-episode (peak) magnitude (charcoal pieces $/ \mathrm{cm}^{2} / \mathrm{charcoal}$ peak) is broadly related to fire severity, size, and taphonomic processes (Higuera et al., 2007) and was also estimated for each of our sedimentary-charcoal records by summing all charcoal counts within a given peak that exceeded the CHAR threshold value.

\section{Sensitivity Analysis}

We include two sensitivity analyses to assess how age model uncertainty, sedimentation rate variations, and temporal scale of analysis can affect the interpretation of recent fire history characteristics. First, we observed that the ${ }^{210} \mathrm{~Pb}$ age for the $21-22 \mathrm{~cm}$ depth interval of the Chadsey Lake core was 537 years younger than the corresponding AMS- ${ }^{14} \mathrm{C}$ date (S2 Table). We analyzed the effects of this age model uncertainty on fire frequency characteristics by creating two distinct age models for Chadsey Lake: one based on all nine ${ }^{210} \mathrm{~Pb}$ age determinations, 
four AMS- ${ }^{14} \mathrm{C}$ ages, and the Mazama tephra, as described above (Figure 2A), and the second, "AMS- ${ }^{14} \mathrm{C}$-based age model" based on all five AMS- ${ }^{14} \mathrm{C}$ ages, the Mazama tephra, and an assigned age of $-64 \mathrm{cal} \mathrm{yr} \mathrm{BP}$ for the core top (Figure 2C).

Second, significant increases in sediment accumulation rate occur at the tops of the Chadsey and Somenos lake records, respectively (Figures 2A,B), a pattern found in other charcoal records dated with ${ }^{210} \mathrm{~Pb}$ methods [(e.g., Sugimura et al. (2008)]). Thus, our second sensitivity analysis estimates fire history characteristics using the "surface-only" portion of each sedimentary record (i.e., from 1,018 to $-64 \mathrm{cal}$ yr BP at Somenos and from 1,088 to $-64 \mathrm{cal} \mathrm{yr} \mathrm{BP}$ at Chadsey). We compare these with the fire history characteristics estimated for the composite records. We use the same age-depth model and CharAnalysis parameters for the surface-only analysis, with two exceptions. First, median sample resolutions are shorter in the surfaceonly analysis (Somenos, 7 years; Chadsey, 7 years) than in composite cores (Somenos, 10 years; Chadsey, 16 years). Second, the window widths used to smooth the background CHAR component are smaller in the surface-only analysis (Somenos, 400 years; Chadsey, 400 years) than in composite cores (Somenos, 1,200 years; Chadsey, 700 years). For the surface-only analyses, we selected the largest window width that the software would use and interpreted our results with the understanding that narrow window widths produce background components that mirror the peaks component of CHAR and detect fewer fire episodes (Mooney and Tinner, 2011).

\section{RESULTS}

\section{Lithology}

We identify three stratigraphic units in the Somenos Lake composite core and one stratigraphic unit in the Chadsey Lake composite core. From the base of the Somenos Lake core to

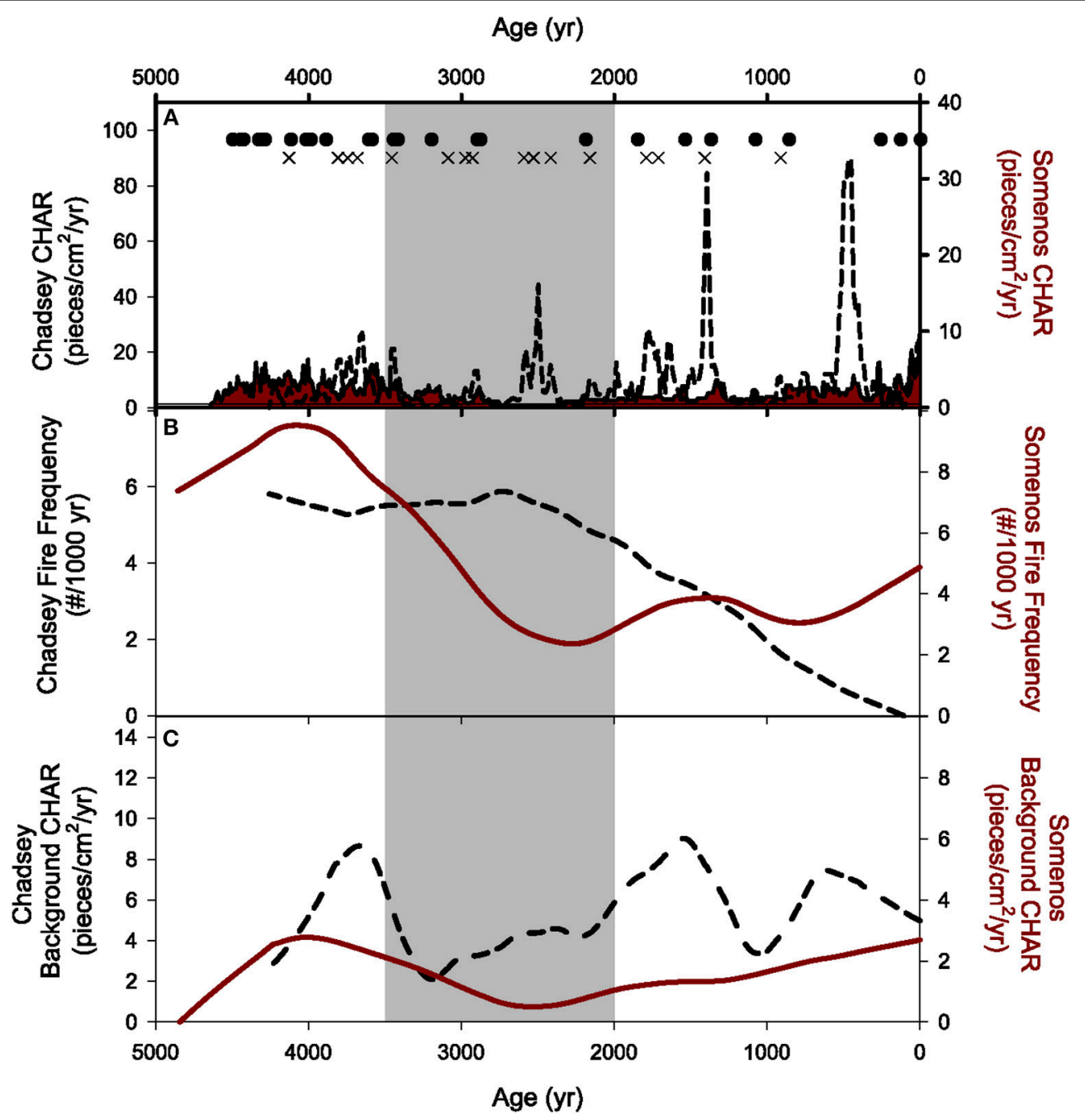

FIGURE 3 | Fire history characteristics of Somenos and Chadsey Lakes over the last 5,000 years. (A) CHAR records from Somenos (red shaded area) and Chadsey (dashed line). Fire episodes indicated with X's (Somenos) and dots (Chadsey). (B) Fire frequency records for Somenos (solid line) and Chadsey (dashed line). (C) Background CHAR for Somenos (solid line) and Chadsey (dashed line). In all panels, gray shaded area represents Zone 2 (3,500-2,000 cal yr BP). 
TABLE 1 | Fire history characteristics of Somenos and Chadsey Lakes over the last $\sim 5,000$ years.

\begin{tabular}{|c|c|c|c|c|c|}
\hline Analysis & $\begin{array}{l}\text { Fire episodes } \\
\text { (\#) }\end{array}$ & $\begin{array}{l}\text { CHAR } \\
\text { (pieces/ } \\
\mathrm{cm}^{2} / \mathrm{yr} \text { ) }\end{array}$ & $\begin{array}{c}\text { mFRI } \\
\text { (yrs) }\end{array}$ & $\begin{array}{c}\text { Back-ground CHAR } \\
\text { (pieces/ } \\
\mathrm{cm}^{2} / \mathrm{yr} \text { ) }\end{array}$ & $\begin{array}{l}\text { Fire frequency } \\
\text { (fires/1,000 yrs) }\end{array}$ \\
\hline Chadsey composite & 16 & $\begin{array}{c}9.67 \\
(89.79-0)\end{array}$ & $\begin{array}{c}214 \\
(150-285)\end{array}$ & $\begin{array}{c}5.45 \\
(9.02-2.10)\end{array}$ & $\begin{array}{c}3.8 \\
(5.89-0.01)\end{array}$ \\
\hline Chadsey AMS- $-{ }^{14} \mathrm{C}$ age model & 17 & $\begin{array}{c}5.17 \\
(36.87-0)\end{array}$ & $\begin{array}{c}242 \\
(166-324)\end{array}$ & $\begin{array}{c}4.49 \\
(9.21-1.12)\end{array}$ & $\begin{array}{c}3.92 \\
(5.34-2.37)\end{array}$ \\
\hline Somenos surface-only ${ }^{a}$ & 6 & $\begin{array}{c}2.2 \\
(0.6-20.2)\end{array}$ & $\begin{array}{c}127 \\
(48-246)\end{array}$ & $\begin{array}{c}1.1 \\
(1.6 \text { to }-0.2)\end{array}$ & $\begin{array}{c}3.7 \\
(0.02-8.7)\end{array}$ \\
\hline Chadsey surface-only ${ }^{a}$ & 7 & $\begin{array}{c}16.35 \\
(89.4-0)\end{array}$ & $\begin{array}{c}190 \\
(71-338)\end{array}$ & $\begin{array}{c}8.22 \\
(24.15 \text { to }-1.23)\end{array}$ & $\begin{array}{c}5.3 \\
(6.36-4.62)\end{array}$ \\
\hline
\end{tabular}

a Only the past 1,018 and 1,088 years of the Somenos and Chadsey Lake composite cores, respectively, were used to compare results to those of the respective surface cores.

$380 \mathrm{~cm}$, the sediment consists of a sedge-like material; clay extends from 380 to $265 \mathrm{~cm}$, and highly organic sediment is found in the top $265 \mathrm{~cm}$. The clay deposition separating sedge peat from gyttja (fine-grained, organic-rich sediment) indicates a change in Somenos Lake's basin hydrology, resulting in a change from marsh to lake conditions. Tephra from the 7,590 cal yr BP-old Mt. Mazama eruption (Hallett et al., 1997) is found at $492-492.4 \mathrm{~cm}$ depth. For this study we constrained our charcoal analysis to the gyttja sediments so confounding effects of lake changes reflected in the sediment types would not be incorporated into our analysis. The Chadsey Lake composite core is comprised of one lithologic unit of gyttja, and the Mazama tephra is found at 406-409 cm depth.

\section{Signal-to-Noise Thresholds}

To obtain a robust reconstruction of local fire history using peak analysis, a sedimentary-charcoal record should have a signal-tonoise index (SNI) greater than three (Kelly et al., 2011). The global SNI for the Somenos Lake charcoal record meets the SNI threshold (median global SNI, 3.96) for the entire record. The Chadsey Lake charcoal record has a high global SNI (median global SNI, 6.23) for the entire record.

\section{Charcoal Records From Somenos and Chadsey Lakes}

The mean CHAR in the Somenos Lake record (interpolated to 10 years intervals) is $1.97 \mathrm{pieces} / \mathrm{cm}^{2} / \mathrm{yr}$, with the highest period of CHAR at $\sim 4,000 \mathrm{cal} \mathrm{yr} \mathrm{BP} \mathrm{(Figure} \mathrm{3A;} \mathrm{Table} \mathrm{1).} \mathrm{The} \mathrm{mean}$ CHAR (interpolated to 16 years sample intervals) at Chadsey Lake is 9.63 pieces $/ \mathrm{cm}^{2} / \mathrm{yr}$, almost 5 times higher than at Somenos Lake (Figure 3A; Table 1).

Over the last $\sim 4,500$ years, sedimentary-charcoal records indicate that Somenos (4855 cal yr BP charcoal record) had 24 fire episodes and Chadsey (4258 cal yr BP charcoal record) had 15 fire episodes. The mFRIs for the two sites were not considerably different (26 years), but have values within the range of variability between the sites [Somenos, 188 years (122 to 259); Chadsey, 214 years (150 to 285)] (Table 2). Six fire episodes occur during
TABLE 2 | Mean fire return intervals (mFRl) for Somenos and Chadsey Lakes.

\begin{tabular}{lll}
\hline Time period & \multicolumn{2}{c}{ mFRI (years) } \\
\cline { 2 - 3 } & \multicolumn{1}{c}{ Somenos Lake } & Chadsey Lake \\
\hline ca. 5,000 cal yr BP to present & $188[122-259]^{\star}$ & $214[150-285]^{\star}$ \\
Zone 1 (ca. 5,000 to 3,500 cal yr BP) & $107.5(30-270)$ & $144(48-320)$ \\
Zone 2 (3,500 to 2,000 cal yr BP) & $233(20-690)$ & $238(48-608)$ \\
Zone 3 (2,000 cal yr BP to present) & $312(170-600)$ & $403(80-912)$
\end{tabular}

[]* natural range of variability (i.e., $95 \%$ confidence intervals of $\mathrm{mFRl}$ for range of analyses) for ca. $5,000 \mathrm{cal} \mathrm{yr} \mathrm{BP}$ to present. () indicate range of fire return intervals in a given zone.

similar time periods (within 50 years) indicating environmental conditions suitable to fire existed at both sites during a common time period $(875,1,385,2,205,2,915,3,465$, and 3,635 cal yr BP at Somenos Lake, and 912, 1,408, 2,160, 2,928, 3,456, and 3,696 cal yr BP at Chadsey Lake). However, the Somenos Lake record records five more episodes during Zone 1 and three more episodes in Zone 3, while the Chadsey Lake record has more episodes during Zone 2 (Figure 3A).

\section{Zone 1 (ca. 4,500 to 3,500 cal yr BP)}

Between ca. 4,500 and 3,500 cal yr BP (Zone 1), both sites experience the overall highest fire frequencies and lowest mFRIs found in the records (Figure 3B). The mFRIs are estimated as 107.5 (range 30-270) years for Somenos Lake and 144 (range 48-320) years for Chadsey Lake. A maximum fire frequency of 9.5 peaks $/ 1,000 \mathrm{yr}$ is reached at $\sim 4,000 \mathrm{cal} \mathrm{yr}$ BP for Somenos Lake. Fire frequency for Chadsey Lake remained fairly consistent through Zone 1 ranging between 5.82 and 5.28 peaks/1,000 yr. Despite the additional fire episodes at Somenos Lake compared with Chadsey Lake during Zone 1, the mFRI of Chadsey Lake (144 years) is within the natural range of variability of the mFRI of Somenos Lake (30 to 270 years) (Table 2). This similarity results from how mFRIs were calculated [i.e., by averaging the time period between fire episodes (Agee, 1993)] and highlights the importance of documenting how mFRI is calculated in fire history studies. Finally, background CHAR trends at Somenos 
Lake suggest a regional increase in biomass burning around 4,000 cal yr BP, decreasing to a minimum around 2,500 cal yr BP during Zone 2 (Figure 3C), whereas the background CHAR for Chadsey Lake varied more than Somenos having three peaks throughout the record at 3,664, 1,552, and $731 \mathrm{cal} \mathrm{yr} \mathrm{BP.}$

\section{Zone 2 (3,500 to 2,000 cal yr BP)}

During the 1,500 years time period of Zone 2, overall background CHAR at Chadsey Lake was low, indicating reduced biomass burning in the region (Figure 3C). The longest fire-free intervals in this zone are $\sim 690$ years $(2,895-2,205 \mathrm{cal} \mathrm{yr} \mathrm{BP})$ at Somenos and $\sim 368$ years $(3,456-3,088 \mathrm{cal}$ yr BP $)$ at Chadsey Lakes. In contrast, the two sites record substantially different fire frequency and mFRIs patterns. Zone 2 represents the period of lowest fire frequency at Somenos Lake (2.36 fires/1,000 years at $\sim 2,260$ cal yr BP); and highest fire activity at Chadsey Lake at $\sim 2,700$ cal yr BP (5.89 fires/1,000 years)(Figure 3B). The mFRI for Zone 2 was 233 years at Somenos Lake and 238 years at Chadsey Lake (Table 2).

\section{Zone 3 (2,000 cal yr BP to Present)}

During Zone 3, fire frequency continues to decline for Chadsey Lake, but slightly increases at Somenos Lake (Figure 3B). However, the 312 (170-600)-year mFRI for Somenos Lake falls within the natural range of variability of the 403 years mFRI for Chadsey Lake in Zone 3 (80 to 912 years) (Table 2). While background CHAR remains consistently low at Somenos Lake, it increases ca. 1,000 cal yr BP and then sharply decreases to present at Chadsey Lake (Figure 3C).

\section{DISCUSSION}

\section{History of Fire Activity, Climate, and Human Habitation \\ Zone 1 (ca. 4,500 to 3,500 cal yr BP)}

In contrast to our sites, the other charcoal-inferred fire histories in southwestern $\mathrm{BC}$ and western Washington document relatively low or medium fire activity between ca. 4,500 and 3,500 cal yr BP compared to the rest of the late Holocene (Wainman and Mathewes, 1987; Gavin et al., 2001, 2013; Brown and Hebda, 2002a,b; Sugimura et al., 2008; Prichard et al., 2009). Low fire activity is largely supported by palynological studies indicating that climate in the Pacific Northwest was transitioning ca. 5,000 cal yr BP from the warm, dry xerothermic conditions of the early Holocene [ca. 9,500-7,000 cal yr BP; (Mathewes and Heusser, 1981; Pellatt et al., 2001)] to the warm, moist mesothermic conditions of the mid Holocene [ca. 7,000 to 4,500 cal yr BP; (Hebda, 1995)] and the cooler, wetter climate of the late Holocene [ca. 4,500 cal yr BP to present; (Heusser, 1983; Pellatt et al., 2001; Brown et al., 2008; Sugimura et al., 2008)]. This transition toward a cooler and wetter climate likely reduced the probability of fire ignition between ca. 5,000 and 3,500 cal yr BP at sites in southwestern BC and western Washington.

Of the 19 regional mid-to-late Holocene sites, only six report similar observations of high fire incidence between ca. 5,000 and ca. 3,500 cal yr BP, and most are attributed to local scale factors. For example, Walsh et al. (2008) claim that the establishment of modern forests, as indicated by pollen analysis, increased fuel production and subsequently led to an increase in fire frequency between ca. 5,400 and 4,600 cal yr BP at Battle Ground Lake in southwestern Washington. Brown and Hebda (2002a) and Hallett et al. (2003) propose that increased fire activity between ca. 5,000 and 3,500 cal yr BP at their high elevation sites (Porphyry, Walker, Mt. Barr Cirque, and Frozen Lakes (Figures 1a,f,i,q, 4c,d) either reflected anthropogenic use of fire to increase the availability of high elevation food sources (e.g., fruiting shrubs) or increased natural ignitions from high elevation lightning strikes resulting from unstable air masses (Rorig and Ferguson, 1999). Derr (2014) also argues that higher charcoal influx between ca. 5,000 and 3,500 cal yr BP at the low-elevation site on Valdes Island (Shingle Point Bog) (Figures 1g, 4f) is attributed to human activity as it coincides with some of the earliest archeological evidence of Indigenous peoples in the Strait of Georgia Lowlands (Grier et al., 2009; Lepofsky et al., 2009; Grier and Kim, 2012). In summary, because regional climate was not conducive to fire (i.e., cool and moist) during Zone 1, high fire activity at these six sites between ca. 5,000 and ca. 3,500 cal yr BP is attributed to local scale factors such as human activity, lightning strikes, and fuel production.

Increased anthropogenic and natural (i.e., lightning) ignitions and increased fuel production are also plausible explanations for relatively high fire activity at Somenos and Chadsey Lakes during Zone 1. However, the lack of local, long-term pollen and/or archaeological studies near Chadsey Lake precludes our ability to conclusively link any single, local scale driver to high fire incidence. Regionally, human presence prior to EuroAmerican settlement is indicated by the frequency of calibrated radiocarbon dates from archaeological sites in the Gulf of Georgia (Lepofsky et al., 2005) (Figure 4k). The closest archaeological sites to Chadsey Lake are located to the east and west of Sumas Mountain in the central Fraser Valley (Lepofsky et al., 2013). While some sites pre-date our $\sim 5,000$-year record at Chadsey Lake and support the possibility of human influence [e.g., the Stave site near Mission, BC (Locher and Berna, 2014)], more evidence is required to link human habitation conclusively to enhanced fire activity at Chadsey Lake during Zone 1.

The onset of summer droughts may also have contributed to locally high fire occurrence between ca. 5,000 and 3,500 cal yr BP. Even though regional climate was relatively cool and moist during Zone 1, evidence of summer droughts is growing. Terrestrial and marine proxy data from the northeastern Pacific indicate that prior to $4,000 \mathrm{cal}$ yr BP, winters and summers were dominated by weak Aleutian Low and strong Pacific High pressure systems, respectively (Barron and Anderson, 2011). As a result, the western interior of North America experienced widespread summer drought (Fritz, 1996), with a particularly dry interval between 6,500 and 4,300 cal yr BP in Washington, Oregon, and northwestern California (Briles et al., 2005). These severe summer droughts were likely conducive to extensive wildfires, contributing to high fire frequency between ca. 5,000 and 3,500 cal yr BP. Thus, in addition to possible local scale drivers, the higher levels of fire activity at our sites and six sites across the region could indicate a strong relationship between summer droughts and fire activity between $\sim 5,000$ and 3,500 cal yr BP. 


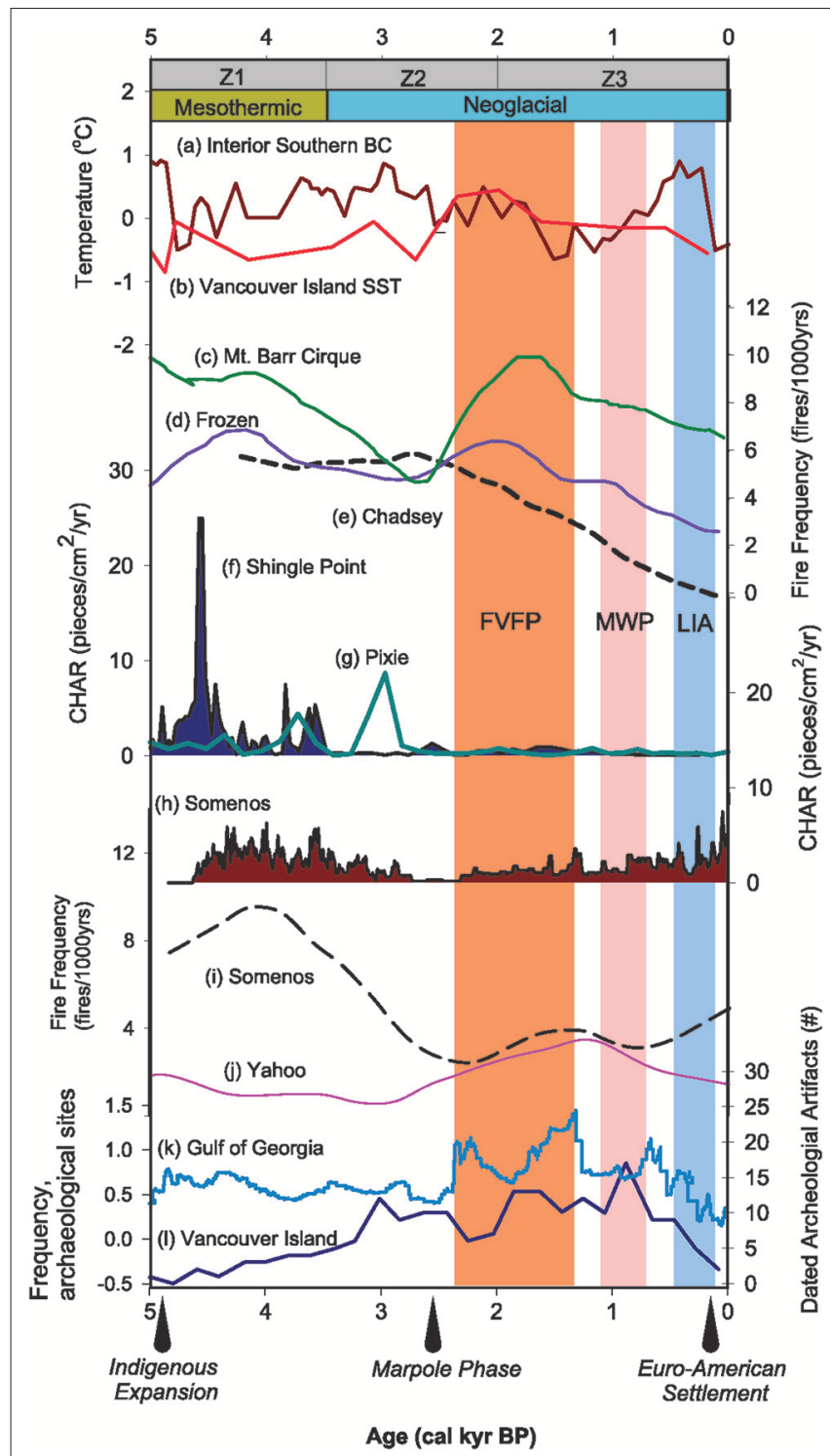

FIGURE 4 | Regional synthesis of charcoal-inferred fire activity and major anthropogenic and climatic changes in southwestern BC and western Washington over the last $\sim 5,000$ years. Gray bars indicate Zones 1 (ca. $5,000-3,500 \mathrm{cal}$ yr BP), 2 (3,500-2,000 cal yr BP), and 3 (2,000 cal yr BP to present). Climate periods depicted are the warm, moist Mesothermic (yellow bars) (Hebda, 1995) and cool, moist Neoglacial (blue bars) (Walker and Pellatt, 2003), and the Fraser Valley Fire Period [FVFP, medium red, Hallett et al. (2003)], the Medieval Warm Period [MWP, light red, Mann et al. (2009)], and the Little Ice Age [LIA, light blue, Grove (2001)] that fall within the Neoglacial. Temperature anomaly records are from (a) interior southern BC [red line, Gavin et al. (2011)] derived from chironomid reconstructions from four lakes in southern-to-southeastern BC (Palmer et al., 2002; Rosenberg et al., 2004; Chase et al., 2008) and (b) alkenone-derived sea-surface temperatures from deep-sea core JT96-09PC off the coast of Vancouver Island (Kienast and McKay, 2001). The mean temperature estimated over 0 to 10,000 cal yr BP was subtracted from all values. Fraser Valley fire frequency records include: (c) Mt. Barr Cirque Lake (Hallett et al., 2003), (d) Frozen Lake (Hallett et al., 2003), and (e) Chadsey Lake (this study). CHAR records are taken from: (f) Valdes Island On-site Bog from Shingle Point (Derr, 2014), (g) Pixie Lake (raw, unsmoothed data) (Brown and Hebda, 2002b), and (h) Somenos Lake (this

(Continued)
FIGURE 4 | study). Vancouver Island fire frequency records include: (i) Somenos Lake (this study) and (j) Yahoo Lake (Gavin et al., 2013). Indications of human presence prior to Euro-American settlement are taken from: $(k)$ frequency of calibrated radiocarbon dates from archaeological sites compiled for the Gulf of Georgia region (Lepofsky et al., 2005), and (I) the frequency of radiocarbon-dated artifacts from 71 archeological sites on the eastern side of southern Vancouver Island [data from Morlan (xbib2005) and compiled by McCune et al. (2013)]. Arrows point to the timing of Indigenous cultural expansion (Grier et al., 2009; Grier and Kim, 2012), the start of the Marpole Phase (2,500-1,000 cal yr BP) (Matson and Coupland, 1995), and the beginning of Euro-American settlement (Boyd, 1999) in the Strait of Georgia Lowlands.

\section{Zone 2 (3,500 to 2,000 cal yr BP)}

Chadsey Lake experienced peak fire frequency (5.9) at 2,736 cal yr BP and then saw a gradual but continuous decline in fire frequency until the present. This information supports this idea that fire conditions in general were more favorable to fire during the mid Holocene than during the subsequent neoglacial period (Figure 3A). This is somewhat similar in Somenos Lake where peak fire frequency occurred around 4,000 cal yr BP and then declined fairly rapidly with the onset of neoglacial conditions in coastal BC, as observed in the pollen records on Vancouver Island and the BC lower mainland (Mathewes, 1973; Pellatt et al., 2001) On nearby Valdes Island, Derr (2014) argues that the large increase in CHAR at Shingle Point Bog ca. 4,000 cal yr BP was likely caused by a shift in anthropogenic fire use, from clearance of the land during the initial occupation period to maintenance of vegetation states, ca. 4,000 cal yr BP (Figure 4f). Given that Shingle Point Bog is located $\sim 25 \mathrm{~km}$ southwest of Somenos Lake, the high CHAR fire episode ca 4,000 cal yr BP in the Somenos Lake record could represent one or several land clearing fires ignited by humans (Figure $\mathbf{4 h}$ ).

The lowest fire activity over the entire $\sim 5,000$ years Somenos Lake record (mFRI, 690 years) occurred in Zone 2 (Figure 4i). Of the 19 other charcoal-inferred fire histories, 15 document similarly low to medium fire occurrence between 3,500 and 2,000 cal yr BP (Wainman and Mathewes, 1987; Gavin et al., 2001, 2013; Brown and Hebda, 2002a,b; Brown and Hebda, 2003; Hallett et al., 2003; Sugimura et al., 2008; Walsh et al., 2008; Derr, 2014). Low fire activity at this time is consistent with an enhanced Aleutian low and weakened Pacific High post 4,000 cal yr BP (Barron and Anderson, 2011) that produced cool and moist Neoglacial conditions ca. 3,500-2,500 cal yr BP) (Ryder and Thomson, 1986; Luckman et al., 1993; Luckman, 1995; Walker and Pellatt, 2003). Relatively low levels of biomass burning in the region between ca. 3,500 and 2,000 cal yr BP, as indicated by background CHAR trends at both Somenos and Chadsey Lakes (Figure 3C), supports our hypothesis that regional climate was the primary driver for declining fire occurrences at both study sites during Zone 2.

Despite cool and moist Neoglacial conditions during Zone 2, the second highest period of local fire activity (mFRI, 238 years) occurred at Chadsey Lake between 3,500 and 2,000 cal yr BP. Fire frequency peaked at $2,736 \mathrm{cal} \mathrm{yr} \mathrm{BP}$ and then maintained a steady decline to the end of Zone 2 until present (Figure 4e). Of the 19 other charcoal-inferred fire histories, only Pixie Lake (Brown 
and Hebda, 2002b) (Figure 4g), Panther Potholes (Prichard et al., 2009), and Martins Lake (Gavin et al., 2001) reveal similarly high fire incidence between 3,500 and 2,000 cal yr BP. The increases in charcoal production at Pixie and Martins Lakes during Zone 2 are relatively minor and thus not fully addressed by Brown and Hebda (2002b) and Gavin et al. (2001). At Panther Potholes, Prichard et al. (2009) suggest several local scale factors that could have contributed to higher fire frequency, including: more productive forests producing more high-severity fires, increased high-elevation lightning ignitions (Rorig and Ferguson, 1999), more anthropogenic ignitions (Lepofsky et al., 2005), and enhanced summer drought conditions (Hallett et al., 2003).

Higher fire activity 2,736 cal yr BP at Chadsey Lake could be a result of intensified summer drought conditions and possible increased anthropogenic ignitions carried from the transition from mesothermic to neoglacial conditions for the region (Hebda, 1995), but evidence is mixed. On one hand, evidence for a strong Aleutian Low and weak Pacific High after $4,000 \mathrm{cal}$ yr BP could indicate that the regional climate continued to become wetter during Zone 2 (Barron and Anderson, 2011). Furthermore, anthropogenic ignitions associated with the Marpole Phase [2,500-1,000 cal yr BP, Lepofsky et al. (2005)] and summer drought conditions related to the Fraser Valley Fire Period (2,400-1,300 cal yr BP, Hallett et al. (2003) occurred after the increase in fire incidence and are therefore not conclusively linked to increased fire frequencies ca. 3,000-2,700 cal yr BP. Interior southern BC (east of the Cascade Mountains) chironomid data show increased temperatures that culminated ca. 3,000 cal yr BP and then decreased progressively until the late Holocene, consistent with the decrease in fire frequency at both Chadsey and Somenos lakes during this time period (Gavin et al., 2011; Figure 4a).

Increased anthropogenic influence at Chadsey Lake during Zone 2 is supported by increased human presence in the Georgia Depression and coastal BC around ca. 3,400 cal yr BP (McCune et al., 2013; Figure 4l). While the lack of local information on historical human activity around Chadsey Lake limits our ability to conclusively link anthropogenic ignition to increased fire incidence during Zone 2, it is possible that humans caused fire ignition near Chadsey Lake between 3,500 and 2,000 cal yr BP. Although broad scale summer droughts set up conditions conducive to fire (i.e., dry fuels), ignition sources would have been needed. Potential ignition sources are lightning and people. It is possible that the increase in human population in the region (McCune et al., 2013; Figure 4l), in combination of broad scale summer drought conditions, may have contributed to fire events at Chadsey Lake.

\section{Zone 3 (2,000 cal yr BP to Present)}

All of the 21 regional sites with at least a 2,000 years, charcoalinferred fire history document higher fire activity or renewed fire occurrence starting between ca. 2,000 and 1,650 cal yr BP (Wainman and Mathewes, 1987; Gavin et al., 2001, 2003, 2013; Brown and Hebda, 2002a,b, 2003; Hallett et al., 2003; Sugimura et al., 2008; Derr, 2014). Yahoo Lake (Gavin et al., 2013) (Figure 4j) and Panther Potholes (Prichard et al., 2009) record higher fire activity earlier (ca. 2,500 cal yr BP) than the majority of sites. There is an increased fire frequency at Somenos Lake around 1,400 cal yr BP, decreasing slightly through the medieval warm period and increasing through the Little Ice Age to present (Figures 3B, 4i). Chadsey Lake sees a consistent decline in fire frequency through Zone 3 (Figures 3B, 4e).

Interpretations of a stronger Aleutian Low and more positive PDO state ca. 1,500 cal yr BP (Barron and Anderson, 2011) are supported by a number of pollen and tree line studies that indicate that regional climate over the last 2,000 years became even more moist and cool compared to the rest of the Holocene (Whitlock, 1992; Pellatt and Mathewes, 1994; Hebda, 1995; Brown and Hebda, 2002a,b). Because regional climate conditions were generally unfavorable for fire ignition, another factor other than regional climate must have been responsible for increased and/or renewed fire ca. 2,000 cal yr BP. Wainman and Mathewes (1987) suggest that increased charcoal pieces ca. 2,000 cal yr BP at Marion Lake could reflect increased runoff and mass movements associated with greater precipitation. In contrast, Brown and Hebda (2002a) use pollen reconstructions to argue that closed canopy forests during the last 2,000 years likely reduced erosive runoff of charcoal, and the development of sophisticated human societies during the Marpole Phase ca. 2,400 cal yr BP (Matson and Coupland, 1995; Lepofsky et al., 2005) were more likely responsible for increased CHAR at their Vancouver Island sites. While both increased fuel production and anthropogenic burning may have contributed to increased charcoal influx and fire activity ca. 2,000 cal yr BP, a clear increase in fire frequency at Somenos Lake is consistent with Indigenous occupation and land management at sites with deep soil Garry oak ecosystems (Brown, 1996; Pellatt and Gedalof, 2014). Increasing late Holocene fire frequency is consistent with increased Garry oak recruitment until the decline of Indigenous populations in the region and increased fire suppression by the colonial government (Pellatt and Gedalof, 2014; Barlow, 2017).

Although regional climate continued to moisten, several pollen, charcoal, and fossil midge records also suggest an onset of summer drought conditions ca. 2,000 cal yr BP (Brown and Hebda, 2002a; Palmer et al., 2002; Sugimura et al., 2008). A warming trend starting ca. 2,600 cal yr BP is evident in central BC (Gavin et al., 2011), Vancouver Island (Kienast and McKay, 2001) (Figure 4b), and Orcas Island in the Georgia Strait (Sugimura et al., 2008). This warming corresponds with increased ENSO activity ca. 2,800 and 1,600 cal yr BP evident from modeling and tropical proxies (Barron and Anderson, 2011). Furthermore, the extensive drought associated with the Fraser Valley Fire Period (FVFP), is documented between 2,400 and 1,300 cal yr BP (Hallett et al., 2003; Figure 4). Regional synchrony of high fire occurrence ca. 2,000 cal yr BP across southwestern BC and western Washington supports dry summer conditions after 2,000 cal yr BP that could have increased the probability of both human and lightning fire ignitions.

Over the past $\sim 1,000$ years, while several studies correlate fire activity with century-scale climate variability, fire behavior at Chadsey Lake shows a decrease in fire frequency whereas Somenos Lake shows an increase over the last $\sim 500$ years. Lucas and Lacourse (2013) (Roe Lake), Walsh et al. (2008) (Battle Ground Lake), and Hallett et al. (2003) (Frozen and Mt. 

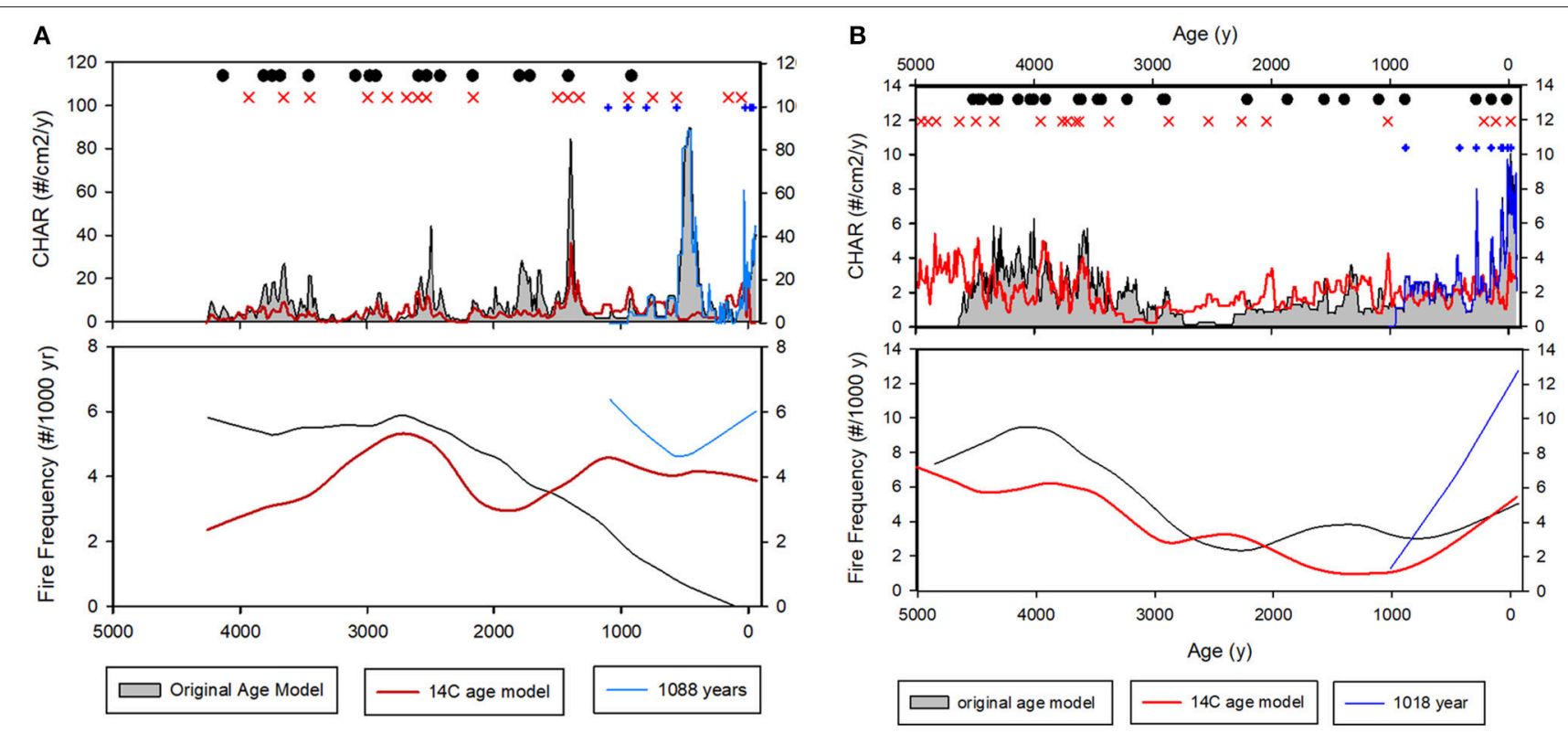

FIGURE 5 | Comparison of recent fire history characteristics between composite, AMS ${ }^{14} \mathrm{C}$, and surface-only sedimentary-charcoal records for (A) Chadsey Lake and $\mathbf{( B )}$ Somenos Lake. For (A,B), fire episodes are shown as black dots for the composite age records, red X for the AMS ${ }^{14} \mathrm{C}$ records, and blue plus symbols for the surface-only record. For CHAR and Fire Frequency composite records are black lines, AMS ${ }^{14} \mathrm{C}$ records are red lines, and surface-only sedimentary-charcoal records are blue lines.

Barr Cirque Lakes) all suggest that the warm, dry conditions during the Medieval Warm Period (MWP, 1,100-700 cal yr BP; Mann et al., 2009) facilitated more frequent fires. Subsequently, the cool, moist conditions of the Little Ice Age (LIA) between ca. 500 and $100 \mathrm{cal} \mathrm{yr} \mathrm{BP} \mathrm{(Grove,} \mathrm{2001)} \mathrm{are} \mathrm{associated} \mathrm{with}$ reduced fire frequencies (Gavin et al., 2003; Hallett et al., 2003; Walsh et al., 2008; Lucas and Lacourse, 2013; Pellatt et al., 2015). The charcoal based fire history for Chadsey Lake is likely driven by the overall decrease in temperature observed in the late Holocene throughout BC (Walker and Pellatt, 2003), whereas the role of Indigenous land management using fire near Somenos Lake is well-documented in the literature (Pellatt and Gedalof, 2014) (Figures 4e,h).

We suggest that greater seasonality may have influenced fire activity over the last $\sim 1,000$ years at Somenos and Chadsey Lakes. While tree-ring records indicate that conditions were warm and dry during the MWP and cool and wet during the LIA (Jones et al., 2001; Weisberg and Swanson, 2003), oxygen isotope measurements from lake sediments show that Pacific Northwest winters were exceptionally wet during the MWP and generally drier during the LIA (Steinman et al., 2012). These seasonal changes in climate may have been the reason why we do not observe consistent records of fire throughout the region.

The intense fire episodes that occurred during the last century at Somenos Lake correspond to tree-ring evidence of widespread regional fires at $82 \mathrm{cal} \mathrm{yr} \mathrm{BP} \mathrm{(Eis,} \mathrm{1962),} \mathrm{charcoal-inferred} \mathrm{fire}$ episodes at 80 and $71 \mathrm{cal} \mathrm{yr} \mathrm{BP}$ at both Roe and Quamichan Lakes (Pellatt et al., 2015), and a doubling of charcoal influxes in a nearby Saanich Inlet sediment core (Heusser, 1983). Since EuroAmerican occupation in the Strait of Georgia Lowlands occurred prior to these high charcoal peaks [ca. 100 cal yr BP, Boyd (1999)], extensive land clearance associated with settlement likely caused these high-severity fires.

\section{Sensitivity of Recent Fire History Characteristics to Age Models and Temporal Scale of Analysis}

Our analysis of two different Chadsey Lake age models and surface-only vs. composite-core fire histories allows us to examine how age model quality and temporal scale affect interpretation of fire histories that could influence fire management strategies.

The AMS- ${ }^{14} \mathrm{C}$-based age model (which excludes all ${ }^{210} \mathrm{~Pb}$ dates) for the Chadsey Lake composite core (Figure 5A) produces some large differences in fire history characteristics that would likely affect interpretations of long-term fire activity, especially concerning recent $(\leq 1,000$ years) fire history (Figure 5A). While the AMS- ${ }^{14} \mathrm{C}$-based age model results in detection of an additional fire episode than the original age (composite) model (Table 1), mFRI calculations over the past $\sim 5,000$ years and for each of the three time zones varied considerably. For example, during the last 1,000 cal yr BP, the composite $\left({ }^{210} \mathrm{~PB}\right.$ and AMS $\left.{ }^{14} \mathrm{C}\right)$ model had 1 fire event, the ${ }^{14} \mathrm{C}$ based model had 5 fire events, and the 1,088 years short model using the composite $\left({ }^{210} \mathrm{~PB}\right.$ and $\left.\mathrm{AMS}{ }^{14} \mathrm{C}\right)$ had 7 fire events (Figure 5A). Additionally, the mean, range, and trend of fire frequency between the two analyses differed substantially (Table 1). For the last $\sim 1,000$ cal yr BP, fire frequency values averaged 4.0 fire peaks per 1,000 years for the AMS- ${ }^{14} \mathrm{C}$-based 
age model whereas estimates made with the original (composite) age-depth model averaged 1.0. The short 1,088 years composite age model analysis averaged 5.3 fire peaks per 1,088. Given that most sedimentary-charcoal fire history reconstructions are based on similar, AMS- ${ }^{14} \mathrm{C}$-based age-depth models (Wainman and Mathewes, 1987; Gavin et al., 2001, 2013; Brown and Hebda, 2002a,b; Brown and Hebda, 2003; Hallett et al., 2003), our results indicate higher temporal resolution and extensive dating of the top of each record (i.e., including ${ }^{210} \mathrm{~Pb}$ age determinations) may offer a different perspective on recent fire activity.

We find differences in short-term fire history characteristics (ca last $\sim 1,000$ years) between the analyses of composite $(\sim 5,000$ years) and the shortened "surface-only" analyses (Figure 5A; Table 1). Each surface-only analysis detected more fire episodes for the comparable $\sim 1,000$ period than the composite core analyses, resulting in lower mFRIs, lower TSLFs, and higher fire frequencies than in the last 1,000 years of the longer, composite core analyses (Table 1). These results suggest that interpretation of recent, millennial-scale fire history characteristics can depend on the temporal scale over which the sedimentary-charcoal records are analyzed. For Somenos Lake, interpretation of recent fire history changed from a low-level fire activity (Zone $3 \mathrm{mFRI}$ of 403 years in the composite core) to high level of fire activity (mFRI of 190 years in the surface-only core) (Figure 5B; Table 1). These data can provide very different interpretations of recent fire histories at a site. Hence caution by land managers when looking at fire histories with different age models needs to be exercised.

Differences in the TSLF were large between the Chadsey Lake composite core (976 cal yr BP), AMS $-{ }^{14} \mathrm{C}$ (629 cal yr BP), and the composite short core ( $7 \mathrm{cal}$ yr BP). The difference between the composite short core and both other models is large and could likely result in different recommendations for restoration and management. Specifically, because the TSLF in the surfaceonly record $(7 \mathrm{cal}$ yr $\mathrm{BP}$ ) is well-below the natural range of variability of mFRI of the composite core (150-285 cal yr BP), fire would not likely be prescribed to restore and/or manage the forests near Chadsey Lake. Alternatively, the TSLF in the Chadsey Lake composite core analysis (976 years) is well over the natural range of variability of mFRI (150-285 years), hence prescribed fire might be recommended for the Chadsey Lake region if this analysis were used (Table 1).

The trend in background CHAR over the last $\sim 100$ years also differs considerably between the composite and composite surface-only analyses for Chadsey and Somenos lakes. Background CHAR for Chadsey Lake showed a very gradual decrease in the composite core analysis, averaging $4.96 \mathrm{pieces} / \mathrm{cm}^{2} / \mathrm{yr}(5.17-4.79)$ over the last 112 years but the composite surface-only core was considerably higher, showing a steady increase averaging $18.90 \mathrm{pieces} / \mathrm{cm}^{2} / \mathrm{yr}(13.94-24.15)$ over the last 105 years, (Figure 6A; Table 1), likely a result of the reduction in the window width from 700 to 400 years in the surface-only core analysis. Similar results were observed for Somenos Lake back ground CHAR with a gradual increase averaging 2.70 pieces $/ \mathrm{cm}^{2} / \mathrm{yr}(2.65-2.76)$ over the last 110 years for the composite core, but the composite surface-only core was considerably higher, showing a steady increase averaging 5.53 pieces $/ \mathrm{cm}^{2} / \mathrm{yr}(4.60-6.51)$ over the last 112 years (Figure 6B;
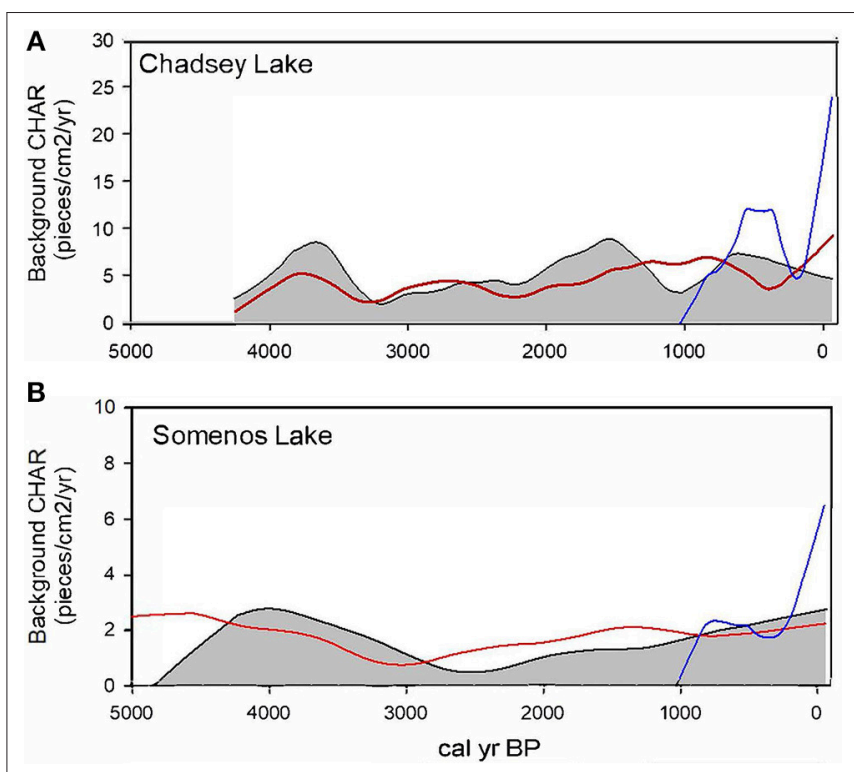

FIGURE 6 | Comparison of background CHAR (pieces $/ \mathrm{cm}^{2} / \mathrm{yr}$ ) over calibrated years before present (cal yr BP) for composite (black line with shading), AMS ${ }^{14} \mathrm{C}$ (red line), and surface-only (blue line) sedimentary-charcoal records for (A) Chadsey Lake and (B) Somenos Lake.

Table 1). This analysis highlights the potential importance of the choice of averaging window. Another reason for the differences in background CHAR is the order-of-magnitude increases in sediment accumulation rates during the last $\sim 150$ years (Figure 2B). As a result of these substantial, recent increases in accumulation rates, the median sample resolutions of the composite cores were much larger (Somenos, 10 years; Chadsey, 16 years) than for the surface-only cores (Somenos, 7 years; Chadsey, 7 years). Larger median sample resolutions in the composite cores result in the detection of fewer fire episodes in the youngest sections of each core (where higher sediment accumulation rates and sample resolutions occurred; Higuera et al., 2010).

These results highlight trade-offs between using short ( $<\sim 1,000$ years) vs. longer $(\sim 5,000$ years) records to establish fire history characteristics for management and restoration purposes, and demonstrate that the choice of record length should depend on the research goal and management objectives. Fire activity inferred from short cores is advantageous if the goal is to examine effects of recent fire suppression or understand contemporary fire-climate linkages to help predict future changes in fire regimes with projected changes in climate and vegetation. However, if the objective is to understand long-term trends and natural ranges of variability of fire activity prior to human influence or to assess the natural and anthropogenic mechanisms driving fire occurrence over time, then longer, Holocene-length records may prove more useful. Nonetheless, even if longer records are advantageous to the goal of the study, analyzing the records at near modern time frames (i.e., $<1,500$ years) where ${ }^{210} \mathrm{~Pb}$ dating can provide better temporal resolution should be considered, particularly if recent fire history characteristics are being 
compared between studies based on different temporal scales of analysis (S1 Supporting Information for Regional Study Sites).

\section{CONCLUSION}

This study presents new sedimentary-charcoal records from Somenos and Chadsey Lakes to provide unique insights into the local fire history of CDFmm and CWHdm forests in the Strait of Georgia Lowlands. In general, our analysis indicates that CDFmm and CWHdm fire regimes in the Strait of Georgia Lowlands have been non-stationary over the last $\sim 5,000$ years. Variation during the mid to late Holocene varies between Somenos Lake on Vancouver Island (CDFmm) and Chadsey Lake in the Fraser Valley (CWHdm). Both sites experience highest overall fire frequency and mFRI in Zone $1(\sim 4,500-3,000 \mathrm{cal}$ yr BP) with Chadsey Lake seeing a continuous decline in fire frequency after a high of 5.9 fire peaks/100 years at $\sim 2,736 \mathrm{cal}$ yr BP. The lack of synchrony after $\sim 4,000 \mathrm{cal}$ yr BP highlights that local site factors (e.g., fuel conditions and abundance, lightning, human ignition, weather, and/or topography) can have a substantial influence on fire occurrence. In contrast, low periods of fire activity in most of the late Holocene at Somenos and Chadsey lakes indicates that broader-scale climatic changes, such as summer droughts, were responsible for driving changes in fire activity.

Our results have several implications for fire management and prescribed burn plans in south coastal forest in BC. First, our analysis supports previous arguments that mean fire return intervals are not "static" (Whitlock et al., 2003), but rather define the natural range of variability of fire disturbances and can assist forest managers in assessing when ecosystem variability has exceeded previous norms (Landres et al., 1999; Swetnam et al., 1999). Other fire history characteristics, such as smoothed fire frequency data, may be better indicators of fire driven ecosystem structure over time periods necessary to identify the changing role of humans and climate. Second, our comparative analysis using different age models and between composite and surface cores indicates that the interpretation of recent fire history can change depending on the quality of age control and on the temporal scale of analysis. Complementary fire history reconstructions over both long and short time frames facilitates better understanding of recent fire regime changes, long-term trends and natural ranges of variability, and climatefire-human linkages. Third, the asynchrony between our sites demonstrates the spatial complexity of local fire histories, largely driven by the diversity of local scale controls on fire activity (e.g., fuel conditions and abundance, lightning, human ignition, weather, and/or topography). This highlights the importance of developing site-specific fire management and prescribed burn

\section{REFERENCES}

Agee, J. K. (1993). Fire ecology of Pacific Northwest forests. Washington, DC: Island Press.

Appleby, P. G., and Oldfield, F. (1977). The calculation of lead-210 dates assuming a constant rate of supply of unsupported $210 \mathrm{~Pb}$ to the sediment. Catena $5,1-8$. doi: $10.1016 /$ S0341-8162(78)80002-2 plans that do not use uniform fire prescriptions and supports future research focused on understanding the natural range of variability of fire disturbances on a local, site-by-site basis.

\section{AUTHOR CONTRIBUTIONS}

SM: study design, graduate student undertook field work, analysis, and main writing; MP: study design, field work, analysis, and writing; KK: study design, analysis, and writing.

\section{FUNDING}

This work was supported by VanCity Environmental Graduate Scholarship to SM; Pacific Institute for Climate Solutions [Project 641052] to MP; Natural Sciences and Engineering Research Council [Discovery Grant RGPIN342251] to KK; and Natural Sciences and Engineering Research Council Canada Research Chair Award to KK. The funders had no role in study design, data collection and analysis, decision to publish, or preparation of the manuscript.

\section{ACKNOWLEDGMENTS}

We are extremely grateful for the logistical and in-kind support provided by Parks Canada. Thanks to Ryan Jaeger, Manoji Gamaralalage, Bill Woods, Celeste Barlow, and other members of the Climate, Oceans, and Paleo-Environments (COPE) laboratory for their field and laboratory assistance and Kendrick Brown and Richard Hebda for supplying Pixie Lake CHAR data for Figure 4. We also thank Tom Guilderson at LLNL for assistance with radiocarbon dating and Cathy Whitlock, Phillip Higuera, and Simon Goring for discussions that helped improve the manuscript. Constructive editorial comments and review by G. Lynn Wingard, Petr Kuneš, and Miriam Jones improved the quality of the manuscript. This work was based on SM's Masters of Resource and Environmental Management project titled Murphy (2016).

\section{SUPPLEMENTARY MATERIAL}

The Supplementary Material for this article can be found online at: https://www.frontiersin.org/articles/10.3389/fevo. 2019.00090/full\#supplementary-material

S1 Supporting Information for Regional Study Sites | Regional fire history study site comparison table.

S2 Table ${ }^{210} \mathrm{~Pb}$ and $\mathrm{AMS}-{ }^{14} \mathrm{C}$ age determinations on Somenos and Chadsey Lake cores.

S3 Text | The effect of different chemicals on charcoal abundance and condition.

Barlow, C. M. (2017). Garry Oak Ecosystem Stand Historry in Southwest British Columbia: Implications for Restoration, Management and Population Recovery. Dissertation/Master's thesis, Simon Fraser University.

Barron, J. A., and Anderson, L. (2011). Enhanced Late Holocene ENSO/PDO expression along the margins of the eastern North Pacific. Q. Int. 235, 3-12. doi: 10.1016/j.quaint.2010. 02.026 
Blaauw, M., and Christen, J. A. (2011). Flexible paleoclimate age-depth models using anautoregressive gamma process. Bayesian Anal. 6:457-474. doi: 10.1214/11-BA618

Boyd, R. (1999). Indians, Fire and the Land in the Pacific Northwest. Corvallis, OR: Oregon State University Press.

Briles, C. E., Whitlock, C., and Bartlein, P. J. (2005). Postglacial vegetation, fire, and climate history of the Siskiyou Mountains, Oregon, USA. Q. Res. 64, 44-56. doi: 10.1016/j.yqres.2005.03.001

Brown, D. R. (1996). Disposing of the Dead: A Shell Midden Cemetary in British Columbia's Gulf of Georgia Region. Dissertation/Master's thesis, University of British Columbia.

Brown, K. J., and Hebda, R. J. (2002a). Ancient fires on southern Vancouver Island, British Columbia, Canada: a change in causal mechanisms at about 2,000 ybp. Environ. Archaeol. 7, 1-12. doi: 10.1179/env.2002.7.1.1

Brown, K. J., and Hebda, R. J. (2002b). Origin, development, and dynamics of coastal temperate conifer rainforests of southern Vancouver Island, Canada. Can. J. Forest Res. 32, 353-372. doi: 10.1139/x01-197

Brown, K. J., and Hebda, R. J. (2003). Coastal rainforest connections disclosed through a Late Quaternary vegetation, climate, and fire history investigation from the Mountain Hemlock Zone on southern Vancouver Island, British Colombia, Canada. Rev. Palaeobot. Palynol. 123, 247-269. doi: 10.1016/S0034-6667(02)00195-1

Brown, K. J., Nielsen, A. B., Fitton, R. J., and Hebda, R. J. (2008). Postglacial evolution and spatial differentiation of seasonal temperate rainforest in western Canada. Holocene 18, 715-727. doi: 10.1177/09596836080 91783

Brown, T. A., Nelson, D. E., Mathewes, R. W., Vogel, J. S., and Southon, J. R. (1989). Radiocarbon dating of pollen by accelerator mass spectrometry. Q. Res. 32, 205-212. doi: 10.1016/0033-5894(89)9 0076-8

Chase, M., Bleskie, C., Walker, I. R., Gavin, D. G., and Hu, F. S. (2008). Midge-inferred Holocene summer temperatures in Southeastern British Columbia, Canada. Palaeogeogr. Palaeoclimatol. Palaeoecol. 257, 244-259. doi: 10.1016/j.palaeo.2007.10.020

Clark, J., and Royall, P. (1995). Particle-size evidence for source areas of charcoal accumulation in Late Holocene sediments of sastern North American lakes. Q. Res. 43, 80-89. doi: 10.1006/qres.1995.1008

Clark, J., Royall, P., and Chumbley, C. (1996). The role of fire during climate change in an eastern deciduous forest at Devil's Bathtub, New York. Ecology 77, 2148-2166. doi: 10.2307/2265709

Daly, C., Gibson, W. P., Taylor, G. H., Johnson, G. L., and Pasteris, P. (2002). A knowledge-based approach to the statistical mapping of climate. Clim. Res. 22, 99-113. doi: 10.3354/cr022099

Derr, K. (2014). Anthropogenic fire and landscape management on Valdes Island, southwestern BC. Can. J. Archaeol. 38, 250-279. Available online at: https:// www.jstor.org/stable/43967084

Dunwiddie, P. W., Bakker, J. D., Almaguer-Bay, M., and Sprenger, C. B. (2011). environmental history of a garry oak/douglas-fir woodland on Waldron Island, Washington. Northwest Sci. 85, 130-140. doi: 10.3955/046.08 5.0205

Eis, S. (1962). Statistical Analysis of Several Methods for Estimation of Forest Habitats and Tree Growth Near Vancouver, BC. Vancouver, BC: University of British Columbia.

Environment Canada, M.S.o.C. (2015). Canadian Climate Normals. 1981-2010 Climate Normals \& Averages. Available online at: http://climate.weather.gc.ca/ climate_normals/index_e.html

Fritz, S. C. (1996). Paleolimnological records of climatic change in North America. Limnol. Oceanogr. 41, 882-889. doi: 10.4319/lo.1996.41. 5.0882

Fuchs, M. (2001). Towards a Recovery Strategy for Garry Oak and Associated Ecosystems in Canada: Ecological Assessment and Literature Review. Technical Report GBEI/EC-00-030. Environment Canada, Canadian WildlifeService, Pacific and Yukon Region. Delta, BC.

Gavin, D., Brubaker, L., and Lertzman, K. (2003). An 1800-year record of the spatial and temporal distribution of fire from the west coast of Vancouver Island, Canada. Can. J. Forest Res. 33, 573-586. doi: 10.1139/ x02-196
Gavin, D. G., Brubaker, L. B., and Greenwald, D. N. (2013). Postglacial climate and fire-mediated vegetation change on the western Olympic Peninsula, Washington (USA). Ecol. Monogr. 83, 471-489. doi: 10.1890/121742.1

Gavin, D. G., Henderson, A. C. G., Westover, K. S., Fritz, S. C., Walker, I. R., Leng, M. J., et al. (2011). Abrupt Holocene climate change and potential response to solar forcing in western Canada. Q. Sci. Rev. 30, 1243-1255. doi: 10.1016/j.quascirev.2011.03.003

Gavin, D. G., Mclachlan, J. S., Brubaker, L. B., and Young, K. A. (2001). Postglacial history of subalpine forests, Olympic Peninsula, Washington, USA. Holocene 11, 177-188. doi: 10.1191/095968301670879949

Gedalof, Z., Peterson, D. L., and Mantua, N. J. (2005). Atmospheric, climatic, and ecological controls on extreme wildfire years in the northwestern United States. Ecol. Appl. 15, 154-174. doi: 10.1890/03-5116

Glew, J. (1988). A portable extruding device for close interval sectioning of unconsolidated core samples. J. Paleolimnol. 1, 235-239. doi: 10.1007/BF00177769

Grier, C., Dolan, P., Derr, K., and McLay, E. (2009). Assessing sea level changes in the southern Gulf Islands of British Columbia using archaeological data from coastal spit locations. Can. J. Archaeol. 33, 254-280.

Grier, C., and Kim, J. (2012). Resource control and the development of political economies in small-scale societies: contrasting prehistoric southwestern Korea and the Coast Salish region of northwestern North America. J. Anthropol. Res. 68, 1-34. doi: 10.3998/jar.0521004.00 68.101

Grove, A. T. (2001). The "Little Ice Age" and its geomorphological consequences in Mediterranean Europe. Clim. Change 48, 121-136. doi: 10.1023/A:1005610804390

Hallett, D. J., Hills, L. V., and Clague, J. J. (1997). New accelerator mass spectrometry radiocarbon ages for the Mazama tephra layer from Kootenay National Park, British Columbia, Canada. Can. J. Earth Sci. 34, 1202-1209. doi: 10.1139/e17-096

Hallett, D. J., Lepofsky, D. S., Mathewes, R. W., and Lertzman, K. P. (2003). 11 000 years of fire history and climate in the mountain hemlock rain forests of southwestern British Columbia based on sedimentary charcoal. Can. J. Forest Res. 33, 292-312. doi: 10.1139/x02-177

Hebda, R. J. (1995). British Columbia vegetation and climate history with focus on $6 \mathrm{ka}$ BP. Géogr. Phys. Q. 49:55. doi: 10.7202/033 030 ar

Heusser, L. E. (1983). Palynology and paleoecology of post-glacial sediment in an anoxic basin, Saanich Inlet, British Columbia. Can. J. Earth Sci. 20, 873-885. doi: $10.1139 / \mathrm{e} 83-077$

Higuera, P., Brubaker, L., Anderson, P., Hu, F., and Brown, T. (2009). Vegetation mediated the impacts of postglacial climate change on fire regimes in the south-central Brooks Range, Alaska. Ecol. Monogr. 79, 201-219. doi: 10.1890/07-2019.1

Higuera, P., Peters, M., Brubaker, L., and Gavin, D. (2007). Understanding the origin and analysis of sediment-charcoal records with a simulation model. Q. Sci. Rev. 26, 1790-1809. doi: 10.1016/j.quascirev.2007.03.010

Higuera, P. E., Brubaker, L. B., Anderson, P. M., Brown, T. A., Kennedy, A. T., and $\mathrm{Hu}, \mathrm{F}$. S. (2008). Frequent fires in ancient shrub tundra: implications of paleorecords for arctic environmental change. PLOS ONE 3:e0001744. doi: 10.1371/journal.pone.0001744

Higuera, P. E., Gavin, D. G., Bartlein, P. J., and Hallett, D. J. (2010). Peak detection in sediment-charcoal records: impacts of alternative data analysis methods on fire-history interpretations. Int. J. Wild. Fire 19, 996-1014. doi: 10.1071/WF09134

Jones, P. D., Osborn, T. J., and Briffa, K. R. (2001). The evolution of climate over the last millennium. Science 292, 662-667. doi: 10.1126/science.1059126

Kelly, R. F., Higuera, P. E., Barrett, C. M., and Hu, F. S. (2011). A signal-to-noise index to quantify the potential for peak detection in sediment-charcoal records. Q. Res. 75, 11-17. doi: 10.1016/j.yqres.2010.07.011

Kienast, S. S., and McKay, J. L. (2001). Sea surface temperatures in the subarctic Northeast Pacific reflect millennial-scale climate oscillations during the last 16 kyrs. Geophys. Res. Lett. 28, 1563-1566. doi: 10.1029/2000GL012543

Landres, P. B., Morgan, P., and Swanson, F. J. (1999). Overview of the use of natural variability concepts in managing ecological systems. Ecol. Appl. 9, 1179-1188. 
Lepofsky, D., Formosa, S., Schaepe, D. M., Lenert, M., and Blake, M. (2013). Mapping sxwoxwiymelh: a pre-contact settlement in the upper Fraser Valley, Southwestern British Columbia. J. Field Archaeol. 38, 309-323. doi: 10.1179/0093469013Z.000000 00064

Lepofsky, D., Lertzman, K., Hallett, D., and Mathewes, R. (2005). Climate change and culture change on the Southern Coast of British Columbia 2,4001,200 Cal. B.P.: an hypothesis. Am. Antiq. 70, 267-293. doi: 10.2307/400 35704

Lepofsky, D., Schaepe, D. M., Graesch, A. P., Lenert, M., Ormerod, P., Carlson, K. T., et al. (2009). Exploring Sto:lo-coast salish interaction and identity in ancient houses and settlements in the Fraser Valley, British Columbia. Am. Antiq. 74, 595-626. doi: 10.1017/S00027316000 48988

Locher, P., and Berna, F. (2014). Holocene human interaction and adaptation to geological and climatic changes in the Lower Mainland, Fraser Canyon, and Coast Mountain area of British Columbia: a geoarchaeological view. Field Guides 38, 53-77. doi: 10.1130/2014.0038(04)

Long, C., Whitlock, C., Bartlein, P., and Millspaugh, S. (1998). A 9000-year fire history from the Oregon Coast Range, based on a high-resolution charcoal study. Can. J. Forest Res. 28, 774-787. doi: 10.1139/x98-051

Lucas, J. D., and Lacourse, T. (2013). Holocene vegetation history and fire regimes of Pseudotsuga menziesii forests in the Gulf Islands National Park Reserve, southwestern British Columbia, Canada. Q. Res. 79, 366-376. doi: 10.1016/j.yqres.2013.03.001

Luckman, B. H. (1995). Calendar-dated, early little-ice-age glacier advance at Robson Glacier, British Columbia, Canada. Holocene 5, 149-159. doi: $10.1177 / 095968369500500203$

Luckman, B. H., Holdsworth, G., and Osborn, G. D. (1993). Neoglacial glacier fluctuations in the Canadian Rockies. Q. Res. 39, 144-153. doi: 10.1006/qres.1993.1018

MacDougall, A., Beckwith, B., and Maslovat, C. (2004). Defining conservation strategies with historical perspectives: a case study from a degraded oak grassland ecosystem. Conserv. Biol. 18, 455-465. doi: 10.1111/j.1523-1739.2004.00483.x

Mann, M. E., Zhang, Z., Rutherford, S., Bradley, R. S., Hughes, M. K., Shindell, D., et al. (2009). Global signatures and dynamical origins of the little ice age and medieval climate anomaly. Science 326, 1256-1260. doi: $10.1126 /$ science. 1177303

Mathewes, R. W. (1973). A palynological study of postglacial vegetation changes in the University Research Forest, southwestern British Columbia. Can. J. Botany 51, 2085-2103. doi: 10.1139/b73-271

Mathewes, R. W., and Heusser, L. E. (1981). A 12000 year palynological record of temperature and precipitation trends in southwestern British Columbia. Can. J. Botany 59, 707-710. doi: 10.1139/b81-100

Matson, R. G., and Coupland, G. (1995). The Prehistory of the Northwest Coast. San Deigo, CA: Academic Press.

McCune, J. L., Pellatt, M. G., and Vellend, M. (2013). Multidisciplinary synthesis of long-term human-ecosystem interactions: a perspective from the Garry oak ecosystem of British Columbia. Biol. Conserv. 166, 293-300. doi: 10.1016/j.biocon.2013.08.004

Meidinger, D., and Pojar, J. (1991). Ecosystems of British Columbia. Special Report Series. Victoria, BC: Government of British Columbia.

Mooney, S. D., and Tinner, W. (2011). The analysis of charcoal in peat and organic sediments. Mires Peat 7, 1-18. Available online at: http://www.mires-and-peat. net/map07/map_07_09.pdf

Morlan, R. E. (2005). CARD, Canadian Archaeological Radiocarbon Database. Retrieved from http://www.canadianarchaeology.ca.

Murphy, S. F. (2016). 5,000-year fire history in the Strait of Georgia Lowlands, British Columbia: Implications for Restoration and Management. Dissertation/Master's thesis, Simon Fraser University.

Palmer, S., Walker, I., Heinrichs, M., Hebda, R., and Scudder, G. (2002). Postglacial midge community change and Holocene palaeotemperature reconstructions near treeline, southern British Columbia (Canada). J. Paleolimnol.28, 469-490. doi: 10.1023/A:1021644122727

Pellatt, M. G., and Gedalof, Z. (2014). Environmental change in Garry oak (Quercus garryana) ecosystems: the evolution of an eco-cultural landscape. Biodivers. Conserv. 23, 2053-2067. doi: 10.1007/s10531-0140703-9

Pellatt, M. G., Gedalof, Z., McCoy, M., Bodtker, K., Cannon, A., Smith, S., et al. (2007). Fire History and Ecology of Garry Oak and Associated Ecosystems in British Columbia. Available online at: https://www.researchgate. net/publication/258113071_Fire_History_and_Ecology_of_Garry_Oak_ and_Associated_Ecosystems_in_British_Columbia_Final_Report_for_the Interdepartmental_Recovery_Fund_Project_733.

Pellatt, M. G., Hebda, R. J., and Mathewes, R. W. (2001). High-resolution Holocene vegetation history and climate from Hole 1034B, ODP leg 169S, Saanich Inlet, Canada. Mar. Geol. 174, 211-222. doi: 10.1016/S0025-3227(00)00151-1

Pellatt, M. G., and Mathewes, R. W. (1994). Paleoecology of postglacial tree line fluctuations on the Queen Charlotte Islands, Canada. Ecoscience 1, 71-81. doi: $10.1080 / 11956860.1994 .11682230$

Pellatt, M. G., and Mathewes, R. W. (1997). Holocene tree line and climate change on the Queen Charlotte Islands, Canada. Q. Res. 48, 88-99. doi: 10.1006/qres.1997. 1903

Pellatt, M. G., Mathewes, R. W., and Clague, J. J. (2002). Implications of a late-glacial pollen record for the glacial and climatic history of the Fraser Lowland, British Columbia. Palaeogeogr. Palaeoclimatol. Palaeoecol. 180, 147-157. doi: 10.1016/S0031-0182(01)00426-6

Pellatt, M. G., McCoy, M. M., and Mathewes, R. W. (2015). Paleoecology and fire history of Garry oak ecosystems in Canada: implications for conservation and environmental management. Biodiver. Conserv. 24, 1621-1639. doi: 10.1007/s10531-015-0880-1

Prichard, S. J., Gedalof, Z.,e., Oswald, W. W., and Peterson, D. L. (2009). Holocene fire and vegetation dynamics in a montane forest, North Cascade Range, Washington, USA. Q. Res. 72, 57-67. doi: 10.1016/j.yqres.2009. 03.008

Rasmussen, K. (2012). Restoring Wetlands in the Somenos Basin. Available online at: https://bcwfbogblog.files.wordpress.com/2012/11/restoring-wetlands-inthe-somenos-basin-kyle-rasmussen.pdf

Reimer, P. J., Bard, E., Bayliss, A., Beck, J. W., Blackwell, P. G., Ramsey, C. B., et al. (2013). IntCal13 and Marine13 radiocarbon age calibration curves 0-50,000 years cal BP. Radiocarbon 55, 1869-1887. doi: 10.2458/azu_js_rc.55. 16947

Rorig, M. L., and Ferguson, S. A. (1999). Characteristics of lightning and wildland fire ignition in the Pacific Northwest. J. Appl. Meteorol. 38, 1565-1575. doi: 10. 1175/1520-0450(1999)038<1565:COLAWF >2.0.CO;2

Rosenberg, S. M., Walker, I. R., Mathewes, R. W., and Hallett, D. J. (2004). Midgeinferred Holocene climate history of two subalpine lakes in southern British Columbia, Canada. Holocene 14, 258-271. doi: 10.1191/0959683604hl703rp

Ryder, J. M., and Thomson, B. (1986). Neoglaciation in the southern Coast Mountains of British Columbia - chronology prior to the late neoglacial maxiumum. Can. J. Earth Sci. 23, 273-287. doi: 10.1139/e86-031

Steinman, B. A., Abbott, M. B., Mann, M. E., Stansell, N. D., and Finney, B. P. (2012). 1,500 year quantitative reconstruction of winter precipitation in the Pacific Northwest. Proc. Natl. Acad. Sci. U.S.A. 109, 11619-11623. doi: 10.1073/pnas.1201083109

Stuiver, M., and Reimer, P. (1993). Extended 14C database and revised CALIB radiocarbon calibration program. Radiocarbon 35, 215-230. doi: $10.1017 /$ S0033822200013904

Sugimura, W. Y., Sprugel, D. G., Brubaker, L. B., and Higuera, P. E. (2008). Millennial-scale changes in local vegetation and fire regimes on Mount Constitution, Orcas Island, Washington, USA, using small hollow sediments. Can. J. Forest Res. 38, 539-552. doi: 10.1139/X07-186

Swetnam, T. W., Allen, C. D., and Betancourt, J. L. (1999). Applied historical ecology: using the past to manage for the future. Ecol. Appl. 9, 1189-1206. doi: 10.1890/1051-0761(1999)009[1189:AHEUTP]2.0.CO;2

Wainman, N., and Mathewes, R. W. (1987). Forest history of the last 12,000 years based on plant macrofossil analysis of sediment from Marion Lake, southwestern British Columbia. Can. J. Botany 65, 2179-2187. doi: $10.1139 / \mathrm{b} 87-300$

Walker, I. R., and Pellatt, M. G. (2003). Climate change in coastal British Columbia - a paleoenvironmental perspective. Can. Water Resour. J. 28, 531-566. doi: 10.4296/cwri2804531 
Walsh, M. K., Marlon, J. R., Goring, S. J., Brown, K. J., and Gavin, D. G. (2015). A regional perspective on holocene fire-climatehuman interactions in the Pacific Northwest of North America. Ann. Assoc. Am. Geogr. 105, 1135-1157. doi: 10.1080/00045608.2015. 1064457

Walsh, M. K., Whitlock, C., and Bartlein, P. J. (2008). A 14,300-yearlong record of fire-vegetation-climate linkages at Battle Ground Lake, southwestern Washington. Q. Res. 70, 251-264. doi: 10.1016/j.yqres.2008. 05.002

Wang, T., Hamann, A., Spittlehouse, D. L., and Murdock, T. Q. (2012). Climate WNA-high-resolution spatial climate data for western North America. J. Appl. Meteorol. Climatol. 51, 16-29. doi: 10.1175/jamc-d-11-043.1

Weisberg, P. J., and Swanson, F. J. (2003). Regional synchroneity in fire regimes of western Oregon and Washington, USA. Forest Ecol. Manage. 172, 17-28. doi: 10.1016/S0378-1127(01)00805-2

Whitlock, C. (1992). Vegetational and climatic history of the Pacific Northwest during the last 20,000 years - Implications for understanding present-day biodiversity. Northwest Environ. J. 8, 5-28.

Whitlock, C., and Larson, C. (2001). "Charcoal as a fire proxy," in Tracking Environmental Change Using Lake Sediments: Terrestrial, Algal, and Siliceous Indicators, eds J. P. Smol, H. J. B. Birks and W. M. Last (Dordrecht: Kluwer Academic Publishers), 75-97.
Whitlock, C., and Millspaugh, S. H. (1996). Testing the assumptions of fire history studies: an examination of modern charcoal accumulation in Yellowstone National Park, USA. Holocene 6, 7-15. doi: 10.1177/0959683696006 00102

Whitlock, C., Shafer, S. L., and Marlon, J. (2003). The role of climate and vegetation change in shaping past and future fire regimes in the northwestern US and the implications for ecosystem management. Forest Ecol. Manage. 178, 5-21. doi: 10.1016/S0378-1127(03)00051-3

Wright, H. E., Mann, D. H., and Glaser, P. H. (1984). Piston corers for peat and lake sediments. Ecology 65, 657-659. doi: 10.2307/1941430

Conflict of Interest Statement: The authors declare that the research was conducted in the absence of any commercial or financial relationships that could be construed as a potential conflict of interest.

Copyright (๑) 2019 Murphy, Pellatt and Kohfeld. This is an open-access article distributed under the terms of the Creative Commons Attribution License (CC BY). The use, distribution or reproduction in other forums is permitted, provided the original author(s) and the copyright owner(s) are credited and that the original publication in this journal is cited, in accordance with accepted academic practice. No use, distribution or reproduction is permitted which does not comply with these terms. 